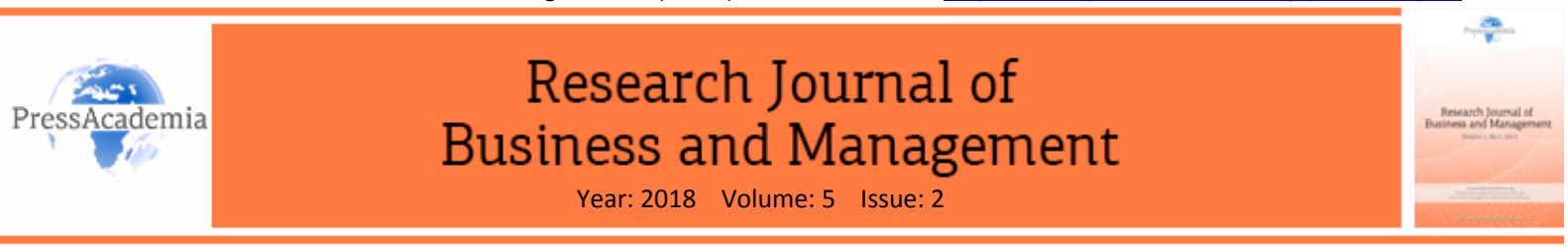

\title{
DO IN-HOUSE POLICY PERCEPTIONS OF TEACHERS WORKING AT STATE SCHOOLS AFFECT THEIR IDENTIFICATION WITH THE INSTITUTION?
}

DOI: 10.17261/Pressacademia.2018.834

RJBM- V.5.ISS.2-2018(7)-p.150-169

\section{Seval Aksoy ${ }^{1}$, Oya Erdil ${ }^{2}$}

${ }^{1}$ Doğuş University, Vocational School, Human Research Management, Istanbul, Turkey. sevalaksoy@dogus.edu.tr.ORCID: 0000-0003-3121-5998

${ }^{2}$ Gebze Technical University, School of Business, Kocaeli, Turkey.

erdil@gtu.edu.tr. ORCID: 0000-0003-3793-001X

\section{To cite this document}

Aksoy, S., Erdil, O. (2018). Do in-house policy perceptions of teachers working at state schools affect their identification with the institution? Research Journal of Business and Management (RJBM), V.5(2), p.150-169.

Permemant link to this document: http://doi.org/10.17261/Pressacademia.2018.834

Copyright: Published by PressAcademia and limited licenced re-use rights only.

\begin{abstract}
Purpose- The purpose of this study is to present the effects of state school teachers' levels of being political in their in-house behavior patterns on their identification with their organization and the mediating effect of their confidence in their colleagues in this interaction. Methodology- This study was conducted with the data obtained from 405 teachers who were employed at state schools in the Kadıköy district of the province of Istanbul - Turkey using a survey form. The data were analyzed using the SPSS and YEM statistic software. Findings- It was found that organizational policy perception had an effect on confidence in colleagues and organizational identification, and confidence in colleagues had an effect on organizational identification. Additionally, it was determined that confidence in colleagues created a complete mediating effect in these effects.

Conclusion- The effects observed in the result of the research are to reduce the confidence in the colleagues in an environment where organizational policy perception is present. Establishing trust in organizations is necessary for employees to identify with their organizations. The research results were supported with theoretical and practical suggestions for the development of those skills and behaviors.
\end{abstract}

Keywords: Organizational policy perception, confidence in colleagues, organizational identification, state schools, teachers, SPSS, YEM JEL Codes: M10, M16, M19

\section{DEVLET OKULLARINDA KURUM IÇi POLITIKA ALGILAMALARI VE GÜVEN DUYGULARI KURUMLA ÖZDEŞLEŞMEYi INŞA EDER MI?}

\section{ÖZET}

Amaç- Yapılan bu araştırmanın amacı, kamuda hizmet veren okullardaki öğretmenlerin kurum içindeki davranış kalıplarında politik olma düzeylerinin örgütleriyle olan özdeşleşmelerine olan etkisini ve bu oluşan etkileşimde çalışma arkadaşlarına duyulan güvenin aracılık etkisini ortaya koyabilmektir.

Yöntem- Bu araştırma, anket formu kullanarak İstanbul İli Kadıköy İlçesi'nde devlet okullarında çalışmakta olan 405 öğretmenden elde edilen data yardımıyla yapılmıştır. Elde edilen veriler SPSS ve YEM istatistik programları marifetiyle analiz edilmiştir.

Bulgular- Örgütsel politika algısının çalışma arkadaşlarına duyulan güven ve örgütsel özdeşleşmeye; çalışma arkadaşlarına duyulan güvenin de örgütsel özdeşleşmeye etki ettiği bulgulanmıştır. Ayrıca, oluşan bu etkilerde çalışma arkadaşlarına duyulan güvenin tam aracılık etkisi oluşturduğu tespit edilmiştir.

Sonuç- Araştırma sonucunda gözlemlenen etkiler, örgütsel politika algısının olduğu bir ortamda çalışma arkadaşlarına duyulan güven azaltıcı yöndedir. Örgütlerin güven oluşturmaları çalışanların örgütleriyle özdeşleşmeleri için gereklidir. Araştırma sonuçları ilgili davranışların geliştirilmesine yönelik teorik ve pratik önerilerle desteklenmiştir.

Anahtar Kelimeler: Örgütsel politika algıSı, çalışma arkadaşlarına duyulan güven, örgütsel özdeşleşme, devlet okulları, öğretmen, SPSS, YEM JEL Kodları: M10, M16, M19 


\section{GiRiş}

İnsanın en değerli kaynak olarak kabul gördüğü günümüz çalışma dünyasında örgütsel amaç ve hedefler bahsi geçen bu kaynağın niteliğine göre şekillenmektedir. Başarıyı elde etmek ve bunu sürdürebilmek amacıyla insan kaynağının çok yönlü yapısının derinlemesine incelenmesi esastır. Doğası gereği birçok parametreyi içinde barındıran sermaye türü olan insan, karmaşık ve eşsiz niteliktedir. Bu karmaşıkığın zenginliği ve çeşitliliği de yine örgütsel manada olumlu getiriler sağlamaktadır. Temelde bilişsel, psikolojik ve davranışsal olmak üzere daha birçok unsura sahip olan insan düşünebilme ve buna bağı olarak karar verebilme kabiliyetiyle diğer canlılardan ayrılmaktadır. Düşünebilme ve ayrıştırabilme özelliğinin bir uzantısı olarak kabul görülen algılama da insanın en belirgin özelliklerinden biridir. Örgütsel anlamda çeşitli algılamalara sahip olan insan birçok olumlu (yardımseverlik, bağlıık, motivasyon araçları, vb.) ve olumsuz (politik davranış, mobbing, muhalif davranışlar, vb.) algıya yönelmektedir. Bunlardan bazıları da araştırmaya konu olan örgütsel politika algılaması, çalışma arkadaşlarına duyulan güven ve bunların önemli bir sonucu olan örgütsel özdeşleşme davranışıdır. Aşağıda ayrıntılı açıklamaları verilen bu üç kavram bütüncül olarak ele alınması halinde örgütsel çıktılarda önemli sonuçlar oluşturmaktadır.

Kurum içindeki politik davranışların başkalarınca algılamaları olan örgütsel politika algısı (Mohan-Bursalı, 2008: 25) zaman zaman yapıcı nitelikte olsa da daha çok olumsuz sonuçlar doğurmaktadır (Chegung ve Law, 2008; Walumbwa vd., 2008; Olkkonen ve Lipponen, 2005). Bu nedenle de politik davranışların doğru algılanabilmesi için hem iş görenlerin hem de öğüt yönetiminin dikkatli davranması kaçınılmazdır (Parker, vd. 1995: 892).

Alan yazına bakıldığında örgütsel özdeşleşmeyi etkileyen kavramlarla ilgili çok sayıda çalışma yapılmıştır. Fakat örgütler için hayati nitelikte olan iş görenlerin huzur ve psikolojik yönden iyi olmaları sağlanarak uzun vadede elde tutulabilmesi için bu alanın yeni araştırmalarla desteklenmesi kaçınılmazdır. Bu nedenle örgütsel politika algısının ve çalışma arkadaşlarına duyulan güvenin örgütsel özdeşleşmeyi nasıl etkilediği konusunda bir çalışmanın literatüre katkı sağlayacağı düşünülerek bu üç alan devlet bünyesinde yer alan okullarda araştırma konusu olarak seçilmiştir. Bu konuda yapılmış olan alan yazın taramasında bu üç değişkenin ayrı ayrı ele alındığı ya da farklı değişkenlerle birlikte araştırıldığı birçok çalışmaya rastlanmış, ancak bu iki değişkenin birlikte örgütsel özdeşleşme üzerindeki etkilerinin incelendiği hiçbir çalışmaya rastlanmamıştır. Özellikle devlet okullarında yürütülmesinin esas sebebi ise statükoya bağlılık ve bunun için politik davranışlar sergileniyor olmasıdır. Bu nedenle de örneklemin demografik özelliklerinin kavramlarla olan etkileşimi de ayrıca sonuç bölümünde ele alınmıştır.

Örgütsel politika algısı ve örgütsel özdeşleşmeyle ilgili yapılan çalışmalar incelendiğinde (Cropanzano vd., 1997; Hochwarter, 2003; Vigoda-Gadot vd., 2003; Kiewitz vd., 2002; Vigoda-Gadot ve Talmud, 2010; Karatepe, 2011; Dutton vd., 1994: 239 263) örgütsel politika algısının yüksek olduğu örgütlerde örgütle özdeşleşmenin düşük olacağı açıktır. Örgütsel politika algısının çalışanların birbirlerine olan güven düzeylerinde de etkisi tıpkı örgütsel özdeşleşmede olduğu gibi negatif yönde oluşmaktadır (Balay, 1999:239; Durdağ ve Naktiyok, 2011: 16).

Çalışma arkadaşlarına duyulan güven ve örgütsel özdeşleşmeyle alakalı yapılan akademik çalışmalar incelendiğinde ise; literatürde bulunan birçok tez çalışması makalede araştırmacılar önemli bir öncül olduğunu bulgulamışlardır (Chegung ve Law, 2008; Walumbwa vd., 2008; Olkkonen ve Lipponen, 2005).

Araştırma amacının yukarıda belirtilmiş olan çeşitli geçmiş araştırmalarla da desteklendiği bu çalışmada; mevcut çalışmalardan farklı olarak, örgütsel politika algısı, çalışma arkadaşlarına güven ve örgütsel özdeşleşme kavramlarının birbirleriyle olan ilişkisinin yanı sıra çalışma arkadaşlarına duyulan güvenin örgütsel politika algısının örgütsel özdeşleşme üzerindeki olumsuz etkisine olan aracılık etkisi de ele alınacaktır. Böylelikle yapılan bu aracılık testiyle literatüre katkı sağlanacaktır.

Çalışmanın literatür incelemesi bölümünde öncelikle her bir kavram örgütsel politika algısı, çalışma arkadaşlarına duyulan güven ve örgütsel özdeşleşme olmak üzere sırasıyla ele alınacaktır. Ardından her bir kavramın birbiriyle olan ilgili alan yazın incelemesinin ardından hipotezlerine ve araştırmanın kavramsal modeline yer verilecek, araştırmanın ana kütlesi, örneklemi ve kullanılan ölçekler teker teker açıklanacaktır. Araştırmada kullanılan ölçüm modeli ve yapısal model, uygulanan analizler ve analiz sonuçlarıyla aktarılarak, kavramlar arasındaki ilişkiler ve demografik özelliklerle olan ilişkisi de ayrıca ortaya koyulacaktır. Araştırma sonuçlarına literatür ile karşılaştırmalı olarak yorumlanacak, sonuçlar doğrultusunda liderler için teorik ve pratik öneriler paylaşılacaktır. Son olarak araştırmanın sınırlılıklarına bağlı olarak gelecek araştırmalar için önerilere yer verilecektir.

\section{LITERATÜR INCELEMESI}

\section{1.Örgütsel Politika Algısı}

Politika kavramı, içinde iki farklı anlamı barındırmaktadır. Preffer (1992) ve Mohan-Bursalı'nın (2008) açıklamalarıyla bunlardan ilki objektif özelliklere sahip olmasıdır. Yazılı olarak beyan edilen ve daha önceden belirli olan, bazı durumlarda örgütsel amaçlara ulaşmak için yol gösterici bir kılavuz olabilme özelliğine sahip biçimsel kararlardır. Bir diğeri ise; örgüt 
ortamında çıkarların bireysel olarak öne çıkarılıp bu yönde hareket etmek ve çalışanların sahip oldukları güç sayesinde diğerlerinin üzerinde izlenim oluşturarak üstünlük kurma çabasıdır. Genel manada ve kapsayıcı olan bu tanımlama örgütsel olarak ele alındığında; açıklanıp karşı tarafa anlatılması oldukça zor olan bir yapıdadır. Vigoda-Gadot ve Talmud'un (2010: 2830) anlatımıyla, çalışma ortamındaki tanımlanması karmaşık olan güç ilişkilerinin bir başka türü olan örgütsel politika, bir tür yönlendirme çabası olarak da anlaşılabilmektedir. Mintzberg'e (1983) göre; avantaj ve dezavantajın çalışanlar arasındaki dağılımıyla ilgilidir.

Örgütsel politika algısı (ÖPA), politik davranışlardan kök alan bir tür algılama biçimidir. Birlikte çalışılan ortamda bireylerin sergiledikleri davranışların çıkar elde etme ve/veya çıkarlarını maksimize edebilmek amacıyla sosyal çevreyi etkileme sürecinin kullanılmasının algılanması olarak genel bir ifadeyle anlatmak da mümkündür. Burada esas olan, bir başka insan tarafından sergilenen bahsi geçen davranışın ortaya konulması veya gerçekleştirilmesi değil; bu davranışa bir başkası tarafından anlam yüklenerek farklı düşünme biçimi geliştiriliyor olunmasıdır (Mohan-Bursalı, 2008: 25). Sergilenen politik davranışların iyi veya kötü, yararlı veya zararlı, gerekli veya gereksiz birer davranış olarak ifade edilmesi bir başkası tarafından nasıl algılandığına bağıı olarak farklı sonuçlar doğuracaktır (Parker, vd. 1995: 892).

ÖPA'nın olumlu veya olumsuz olması durumlarında iş görenlerce birlikte çalıştığı mesai arkadaşlarına ve bağlı bulunduğu yöneticisine karşı bazı tutumlar geliştirerek davranış kalıplarını şekillendirici rol oynaması söz konusudur (Valle ve Witt, 1997). Bazen, sergilenen bazı davranışlar sembol niteliğinde olup; anlamada bireylere zorluk yaşatabilmektedir. O nedenle, algılama bireye bağlı gelişebilecek bir durum olmasından dolayı izlenen her davranışın politik birer özellik sergiliyor olması veya aksi özellikte olması gibi kesin ve net bir cevap herkes tarafından kolaylıkla verilememektedir. Politik davranışların algılanması sübjektif nitelikte olduğu için kaynakların kıt olması durumunda iş görenlerin sergilediği davranışlar diğerleri tarafından politik olarak algılanmaya müsait konumdadır.

Biçimsel kurallar çerçevesinde ifade edilmeyen ve algıya bağlı şekillenen politik davranışlar, daha çok herkesin açıkça göremediği ve şahit olamadığı şekilde gerçekleşebilir. Bu nedenle bu davranışlar, birkaç iş görenin diğer iş görenlerin çıkar ve menfaatini, kaynaklardan alacağı payı nispeten azaltıcı şekilde örgüt amaçlarının öngörmediği ve yazılı kurallarla onaylanmayan davranışların sergilemesiyle ortaya çıkmaktadır (Ferris ve Kacmar, 1992; Ferris vd.,1996). Özellikle belli grup veya bireyler tarafından sergilenen bu davranış için çıkarını artırmak ve yönetime yakın olmak adına bahsi geçen bu gruplara dâhil olabilme gayreti söz konusudur. Bunu yaparken iş görenler bir başkasını suçlamak, karalamak ve ona iftira atarak örgütte yer alan kaynakları (ekonomik, bilgi, vb.) kendine sevk etme eğiliminde olmaktadır (Başar, vd., 2015). ÖPA, sergilenen bu davranışları bireyin kendi yaptığı davranışları da göz önünde bulundurarak yorumlaması ve belli bir kategoriye yerleştirmesidir. Ferris ve Kacmar'a (1992) göre, iş gören zamanla politik davranış sergileyen kişi veya gruplara dâhil olma çabası gütme eğilimi sergilemeye de açıktır.

Politik davranışlarda güdülen amaca göre bu davranış türü örgütün geneli tarafından onaylanmayan bir özelliği de sahiptir. Örgütün kabul sınırlarında kalan bazı araç ve davranış kalıpları dâhilinde sergilenen davranışlar eğer örgütün çıkarlarına ve amaçlarına olumlu olarak yansıyorsa bu davranış türü politik sınırlarda ele alınmamaktadır. Aksi durum olan, sadece bireysel çıkarlara yönelik olması halinde kınama, kabul görmeme sonuçları doğurmaktadır. ÖPA, yapısı gereği kapsamlı bir süreçtir. Bu nedenle, iş görenler kendilerine yardımı dokunacak kişilere yaranabilmek amacıyla gereğinden fazla zaman harcamak durumunda kalırlar. Bu süreç kapsamında ilgili davranış kalıbından yararlı ve tam tersi durum olan zararlı sonuçlarla karşılaşmak da kaçınılmazdır. Kazanım sağlayan taraflar bunu örgütsel anlamda gerekli bir mekanizma olarak kabul etmektedirler (Mintzberg, 1985; İşcan, 2005).

Toparlanıldığında; ÖPA, örgütsel politika içeren davranışların doğrudan veya dolaylı olarak algılanmasıdır. Oluşacak davranışın üç temel özelliği olması gerekmektedir (Ferris vd., 1996; Kacmar ve Carlson, 1997; Vigoda, 2000). Bunlardan ilki; sosyal etki oluşturmak amacıyla birey ve grupların harekete geçmesidir. Bir diğeri ise; "davranışı başlatan" ve sonuçtan etkilenen taraf olan "hedef" konumuyla farklı sıfatlara sahip olan iki tarafın gerekliliği şartıdır. Sonuncu özellik ise; kazanımların maksimize edilmesiyle yakından ilgilidir. Bu üç özelliğin bir arada olmasıyla ÖPA'yı Andrews ve meslektaşlarının (2003) anlatımıyla birey ve örgüt düzeyinde olan bütün davranışları kapsamına almak üzere; "grubun veya bireyin örgüt içinde gücü elinde bulunduran kişilere yönelik olarak sosyal etki çabaları" olarak kapsamlı bir biçimde ifade etmek mümkündür (Cropanzano vd., 1997).

\section{2.Çalışma Arkadaşlarına Duyulan Güven}

İnsanların sayısız ihtiyacından biri olan güven, yaşamı devam ettirebilme, kurulan ilişkiler ve iş yapış biçiminde sürekliliği sağlayabilme ve psikolojik anlamda iyi oluş hali için temel oluşturmaktadır. Koşulsuz bağlanmadan uzak olan güven; herhangi bir kuşku olmaksızın bağııı̆̆a temel oluşturmaktadır. Temel ihtiyaçlarımız olan fizyolojik ihtiyaçlarımızdan sonra kendine yer bulan güven ihtiyacı birçok yönden ele alıp değerlendirmeye elverişli bir yapıdadır. Bireylerin birbirlerine yönelik olarak duydukları güven özel hayatlarını şekillendirirken; insan hayatında bir başka yönü ifade eden çalışma yaşamında güvenin varlığı da kaçınılmaz bir gerekliliktir. Çalışma yaşamındaki güven örgütsel güven olarak alan yazında kendine yer bulmaktadır. Özel yaşamda bahsi geçen güvende olduğu gibi örgütsel güven de iş gören olan bireyin bir algılama 
biçimdir ve çok yönlü bir değerlendirmeye tabiidir. Güven, bireye bağlı oluşurken örgütsel güven örgütün tamamını değerlendirmeye almaktadır. Örgütsel güven, Demirel'in (2008: 184-185) ifadesiyle, çalışanların karşılıklı olarak tutarlı davranışlar sergilemesidir. Bunu destekleyen bir başka ifadeyle beklenti ve itimat etmeyi içeren bir anlatımla Gilbert ve Tang’a (1998: 321) göre de yöneticinin dürüstlüğü ve çalışana verilen sözlerin yerine getirilmesindeki olumlu bekleyiştir.

Alan yazın incelendiğinde örgütsel güven algısı temelde üç farklı alt boyutta ele alınıp açıklanmaya çalışımaktadır. Bunlardan ilki çalışılan kuruma yani örgüte duyulan güven algısıdır (Tan ve Tan 2000). Tek tek bireylere duyulan güvenin çok daha ileri aşaması olan bu boyutta iş gören çalıştığı örgütü bir bütün olarak ele alıp değerlendirir ve buradan yaptığı çıkarımlara bağlı olarak olumlu veya olumsuz yönde güven algısını oluşturur. Daha bütüncül ve kapsayıcı bir yapısı olan örgüte duyulan güven algısı; birlikte çalıştığı yönetici veya amiri, çalışma arkadaşları, örgütün uygulama ve politikalarının bir bütün olarak değerlendirilmesi sonucunda kendine yer bulmaktadır (Kling, 2004: 46-47; Tüzün, 2006: 108-109). İkinci bir boyut olarak ele alınan ise; yöneticiye duyulan güven algısıdır (Deluga, 1994). Yöneticiye duyulan güven algısı örgüte duyulan güvene nazaran daha dar bir kapsama sahiptir. Yani, iş görenlerin doğrudan veya dolaylı olarak bağlı çalıştıkları yöneticilerine karşı oluşan algılarıdır ve yine bireysel ilişkilere dayandırılmaktadır. Ilişsilerin kalitesine dayalı oluşan bu algı, Durdağ ve Naktiyok'un (2011: 14) ifadeleriyle iş görenlerin yöneticilerinin sergilediği davranış, paylaşım ve yaklaşıma bağlı olarak şekillenen ödül veya ceza olarak da tanımlanabilmektedir. Başta da anlatıldığı üzere bu alt boyutta da bir itaat ve bu itaate bağlı olarak oluşan bir razı oluş gerçekleşmektedir. Şöyle ki; yöneticinin davranışlarına bağı oluşan pozitif güven algısı yönetici vasıtasıyla oluşabilecek her türlü sonuca razı oluşu da temsil etmektedir (Lapierre, 2007: 273). Bu boyuttaki güven ilk boyutta yer alan örgüte duyulan güvenin oluşmasında bir öncül niteliğindedir

Araştırmaya konu olan ve diğer iki güven algısına kıyasla çok daha mikro ölçekte incelenen örgütsel güven alt boyutu ise çalışma arkadaşlarına duyulan güven (ÇADG) olarak alan yazında kendine yer bulmaktadır (Ferres, Travaglione ve Connell, 2004). ÇADG düşünüldüğünde, insan doğası gereği muhakkak bir etkileşim ve iletişime ihtiyaç duymaktadır ve bu durum sadece özel yaşamındaki insanlarla sınırlı kalmayarak çalışma ortamında da zaruri bir gereklilik olarak kabul edilmektedir. Bahsi geçen iletişim ve etkileşim zamanla biçimsel olan ve biçimsel olmayan grupların oluşumuna imkân vermektedir. Oluşan gruplar yardımıyla örgütsel amaçlara daha verimli sonuçlar elde ederek ulaşmak kolaylaşmaktadır. Burada esas olan ise; ulaşılan verimli sonuçlarda çalışanlar arasında kurulan ilişkilerin güvene dayalı olarak inşa edilmiş olmasıdır. Örgütsel güvenin adım adım ve belki de en önemli aşaması olan ÇADG bir binanın temeline benzetilirse kuşkusuz ki hatasız bir benzetme yapılmış olacaktır. Young'un (2009: 4) söylemiyle gerek aynı bölüm gerekse emsal seviyede olan işgörenleri ifade eden çalışma arkadaşlığı; güç ve yetki bakımından da eşitliği ifade etmektedir. Güven kavramının özü itibariyle itimat ve bir beklentiyi esas alma ÇADG'de de kendini göstermektedir.

ÇADG, iş görenlerin karşılıklı olarak ahlaki standartlarda iş görme, adaletli bir ortam ve tutarlı bir davranışın ortaya konulması beklentisini ifade etmektedir. Karşılıklı etkileşim temeline dayanması nedeniyle de bireysel çıkarların gözetiminden daha çok karşılıkı çıkarların maksimize edilmesini ve paylaşımlarda dürüstlük ve açıklıkla saygı çerçevesinde davranışlar sergilenmesi en önemli beklentilerdendir (Polat, 2007: 36). İnsan yaşamının büyük bir bölümünün geçirildiği çalışma ortamlarında iş görenlerin birebir muhatap olduğu ve birlikte doğrudan ilişkide olduğu çalışma arkadaşlarının tutum ve davranışlarından etkilendikleri kaçınılmaz olarak açıktır. Bu nedenle, iş görenler arasındaki uyum ve açık iletişim hayati önem taşımakta ve çatışma ortamına zemin oluşturmamalıdır.

ÇADG, iş görenlerin oluşturduğu biçimsel olan ya da biçimsel olmayan gruplardaki kişilerce sergilenen davranışlarda rasyonel, tutarlı ve yapıcı bir ilişkiyi beklediğini de açıkça ifade etmektedir. Böylece, Mowday'in (1998) anlatımında olduğu gibi birey, yer aldığı grubun içinde deneyimlediklerine dayalı olarak örgütüne bağııı̆ı, iş yaşamında yüksek kaliteyi de beraberinde getirecektir. Yukarıda da anlatılmaya çalışıldığı üzere; bireyin eşit ve adil ortamlarda yer alıyor olması adaleti sağlayacak ve karşılıklı olarak çıkar eşitsizliğinden bireyi uzaklaştırarak ÇADG düzeyini de iyileştirecektir. Bunun içinse; kullanılan prosedür ve politikaların açık ve etkin olması gereklidir (Shaw, 1997). Bir iş görenin çalışma arkadaşlarının da rasyonellik sınırlarında olmak koşuluyla en az kendisi kadar sorumluluk almaları, mesleki becerilerinin denkliği, kurallara uyum göstermeleri ve yıkıcı düzeyde politik davranış sergilememeleri ÇADG’yi önemli ölçüde güçlendirici etkidedir.

\section{3.Örgütsel Özdeşleşme}

Özdeşleşme bir bütün olmayı ortaya koymaktadır. Freud'un (1938) ifadeleriyle "başka biriyle duygusal bağ" (Akt: Gautam, vd., 2004: 302) olarak açıklanmaya çalışılırken; Lee'ye (1971: 214) göre ise; "ait olma, sadakat ve paylaşılan özellikler" olarak ortaya konulmaktadır. İnsan, doğası gereği yalnız yaşayıp yalnız hareket edemeyeceği sebebiyle sosyalleşme çabasını, psikolojik ve fizyolojik intiyaçlarını ortaya koyan birlik davranışı içerisindedir. Doğrudan ya da dolaylı olarak ilişkide bulunulan kişi veya kurumla olan yakınlık derecesinde bütünlük çağrışımı yapan ifade, birbirini tamamlamaya yönelik bir anlatımı da barındırmaktadır. Burada güdülen amaçsa; karşılaşılan zorluklara yönelik bireyin kendini güçlü hissetmesi maksadıyla bir gruba ait olma duygusunu ifade edebilmektir. Bireyler arası olduğu gibi örgütsel anlamda da kendine yer bulan özdeşleşme, yine bir bütün olma halinde kendini göstermektedir. Patchen'in (1970) yaptığı çalışma sonrasında örgütsel özdeşleşme (ÖÖ) kavramıyla örgütsel davranış alan yazınında kendine yer bulmuştur (Gautam, vd., 2004: 302). 
Bireyin yer aldığı örgüte karşı hissedeceği ait olma duygusu temeline dayanan ve aksi iddia edilemeyecek düzeyde önemdeki ÖÖ, köklerini Tajfel ve Turner (1979) tarafından oluşturulan "ben kimim?" sorusuna cevap arayan Sosyal Kimlik Kuramı'ndan almaktadır (Tajfel, 1978; Tajfel ve Turner 1979, 1986; Ashforth ve Mael 1989; Mael ve Ashforth, 1992; Dutton vd., 1994; Rousseau, 1998; Van Knippenberg ve Van Schie, 2000; Hogg ve Terry, 2000; Bergami ve Bagozzi, 2000; Van Dick, 2001). Bahsi geçen kurama göre, bir birey kendisini tanımlarken çevresinde olan diğer insanları tanımlayarak, biz ve ötekiler mantığıyla birbirinden farklılık gösteren gruplarda değerlendirmeye almaktadır (Ashforth ve Mael, 1989; Tak ve Çiftçioğlu, 2009: 102). İlgili kuramın savunduğu bir diğer görüşse, Demirtaş'ın (2003: 123) da belirttiği gibi; bir bireyin bir gruba üye oluşunu örgütsel ya da biçimsel olmasından daha öteye götürmektedir. Daha fazla yakınlık, biz olma hali, birlik ve bütünlüğü, yüksek düzeyde aidiyet halini ve bunların da ötesinde iş görenin hem algı hem de bilişsel olarak faaliyet gösterdiği örgütünü her haliyle benimseyip kabul etmesidir.

Bir başka anlatımla; ÖÖ’yü, bir iş görenin tıpkı ailesini bir başkasına tanıtırken kullandığı ifadeleri çalıştığı kurumdan da bahsederken de kullanması gibi düşünmek de mümkündür. Yani, eğer birey yüksek düzeyde bir benimseme ve her bakımdan bir kabullenme sergiliyorsa ya da tam aksi bir durum söz konusuysa burada aslında kendini tanımlamada bulunduğu seviyeyi anlatıyor demektir. ÖÖ, bir iş görenin kendini bir başkasına anlatırken; kullandığı ifadeleri içinde yer aldığı örgüt için de kullanması olarak kabul etmektedir. Hemhal olma veya yekvücut olma olarak da ele alınan öö bir iş görenin örgütünün özellikleriyle benzersiz olarak tanımlamasıdır (Dutton, Dukerich ve Harquail, 1994: 239-240).

Sosyal kimlik ediniminin bir sonucu olan ÖÖ, Lee'nin (1971: 214-215) örgüt ifadesinin de kullanarak açıklamak istediği özdeşleşme kavramını "bir gruba ait olma hissi" şeklinde "örgüt üyelerinin ortak amacının olması ve bireyin örgütteki fonksiyonunun kendi ihtiyaçlarını karşılamak için uygun olduğunu düşünmesi" olarak anlattığı görülmektedir. Yukarıda birçok araştırmacı tarafından tanımlaması yapılmaya çalışılan ÖÖ kavramı için alan yazında benzerlik gösteren bazı tanımların varlığı mevcuttur. Bunlardan bazıları; ÖÖ’yü "örgütle bir olma hissi” olarak tanımlarken (Tolman, 1943; Akt: Mael ve Ashforth, 2001: 197); yine benzer bir anlayışla Cheney (1983: 342) de "bireylerin, kendilerini sosyal alandaki diğer unsurlarla ilişkilendirdiği aktif bir süreç" şeklinde anlatmaktadır. Bir başka tanımlamada da "bireylerin grupla bir olma ya da gruba ait olma algısı" vurgusu yapılmaktadır. Dutton ve meslektaşlarının (1994: 242) yaptığı tanımlamada "birey ve örgüt arasındaki bağlıık hissi" ifadesiyle ÖÖ anlatılmaya çalışılmaktadır.

ÖÖ için yapılan açıklama ve tanımlamalardan hareketle; en öne çıkarılan olguların "bir gruba ait olma" veya "grupla bir olma" olduğu açıkça görülmektedir. Burada dikkat çeken özelliğin iş gören konumundaki bireyin bireysel düşünce, algılama ve değerlendirmelerinin ÖÖ’ye yön verdiği ve yapılan sübjektif değerlendirmedir. Oluşturulan bu yönlendirmede birey ve örgüt arasında oluşacak duygusal bağın niteliği de şekillenmektedir.

\subsection{Kavramlar Arasındaki İlişkiler ve Hipotezlerin Geliştirilmesi}

Bartel'in (2001: 379) ifadesiyle; bir örgütle birlik içinde olunarak aidiyet hissetme olarak tanımlanabilen ÖÖ, doğası gereği birçok öncül (örgütsel adalet, örgütsel güven, örgütsel imaj, vb.) niteliğinde kavramla ilişki içerisindedir. Araştırmaya konu olan değişkenlere bakıldığında bunlar ÖPA ve ÇADG olarak incelenmiştir.

Alan yazında ÖÖ'nün iş görenler arasındaki ilişkinin niteliğine (yakın veya uzak, yapıcı veya yıkıcı, vb.) göre değişeceği Mael ve Ashforth (1992) tarafından anlatılmaya çalışılmıştır. Burada esas olan karşılıklı paylaşımlarda bireylerin açık iletişim kurması ve buna bağlı olarak paylaşımlarda sosyal bağları güçlendirmeye yönelik çaba göstermeleridir. Böylelikle, kurulan iletişimdeki açıklık, arka planda herhangi bir aksaklık veya bireylerarası kandırmacanın olmadığını ortaya koyarak bireyin ÖÖ’sünü artıracaktır. Aksi durumda ise Dutton ve arkadaşlarının (1994: 239-263) da ifade ettiği gibi sergilenecek politik bir davranışın işgörenleri birlik olma duygusundan uzaklaşılarak ÖÖ’lerini azaltacaktır.

Bir diğer bakış açısıyla; örgütte yer alan kaynakların dağılımındaki adalet de ÖÖ’yü ciddi anlamda etkilemektedir. Özellikle de kaynak dağılımında politik nedenler varsa ve bu nedenlerden dolayı yaşanan bir mahrumiyet söz konusuysa iş gören kendini bütünün bir parçası olarak görmekten uzaklaşacaktır. ÖÖ, yapısı gereği hem bilişsel hem de psikolojik niteliktedir. Ailenin bir üyesi olmaktan ziyade değer görmeyen ve fazlalık olarak görüldüğü algısı oluşacaktır. Böyle olmasından dolayı; herhangi bir politik nedenden ötürü kendine acımasız ve insafsızca davranıldığını düşünen iş görende örgütüne yönelik duygusal bir uzaklaşma gözlemlenmektedir. Vigoda'nın (2000: 330) da anlatmaya çalıştığı gibi ÖPA'ya sahip olan bir iş görende örgütsel aidiyet ve kimlik ediniminde önemli düşüşler yaşanmaktadır. Bahsi geçen düşüşler ilerleyen süreçte istenmeyen sonuçlar olan düşmanca tavırlar ve işi aksatmaya kadar varabilmektedir.

Yapılan birçok araştırmada da (Cropanzano vd., 1997; Hochwarter, 2003; Vigoda-Gadot vd., 2003; Kiewitz vd., 2002; VigodaGadot ve Talmud, 2010; Karatepe, 2011) ÖPA olması hallerinde örgütsel bağlılık ve daha ötesi olan ÖÖ’nün azalacağı ifade edilmektedir.

Bir iş görenin örgütüne ve buna bağlı olarak birlikte çalıştığı insanlara yönelik güven duygusu kuşkusuz ki bazı öncülleri de gerektirmektedir. Bahsi geçen bu öncül ifadesinden biri çalışanların birbirlerine karşı politik davranışlarıdır. Bu davranış kalıplarının taraflarca algılanış düzeyi de en az davranışın ortaya konulması kadar önemlidir. Adaletli bir işleyişi de 
bünyesinde barındıran politik davranışlar güven duygusunu önemli ölçüde (olumlu ve olumsuz yönde) yönlendirmektedir. Düzeni, birlikte hareket etmeyi ve karşılıklı güveni inşa eden adaletli ve açık bir işleyiş çalışma ortamları için fazlasıyla önem teşkil etmektedir. Nasıl ki politik davranışların azlığı adaletli bir dağıtımı gerekli kılmaktaysa çalışanların güven duygusunu da artıııı bir unsur görevi de görmektedir. Bunun yanı sıra ÖÖ için de olmazsa olmaz bir öncülü niteliğindedir (Chegung ve Law, 2008; Walumbwa vd., 2008; Olkkonen ve Lipponen, 2005). Politik davranışların sergilenmesi iş görene ait olma hissini veremeyeceğinden dolayı istenmeyen bir sonuç olan örgüte yani çalışılan kuruma olan yüksek bağlılık olan özdeşleşmeye olumsuz bir etki oluşturmaktadır.

Benzer şekilde örgüte birçok yönden duyulan güven (yöneticiye, örgüte ve çalışma arkadaşlarına) çalışanların moralini iyileştirmektedir. Buna bağlı olarak artan motivasyonla örgüte ve birlikte çalıştığı bireylere uyum çabası ortaya çıkmaktadır. Uyumun önemli bir sonucu olan kimlik edinimi ve birlik olma isteğiyle bireyde ÖÖ oluşmaktadır (Polat, 2009).

Ayrıca, iş görenler politik davranışların olmadığı bir çalışma ortamında güven içinde olmaktadır. Psikolojik manada da kendilerini rahat hissetmektedirler. Böylece, örgütsel bağlılık düzeyi artış halinde olarak; yerine getirmekle yükümlü oldukları işlerine kendilerinden de bir şeyler katarak katkı sağlamaya yönelim oluşmaktadır (İşcan ve Naktiyok, 1990: 181).

İletişimdeki açıklık ve riyakâr davranışlardan uzak olma, bireysel çıkarlara nazaran daha çok bütüne fayda sağlayacak davranışlar sergileten durumlar ÖÖ'ye olumlu etki etmektedir. Nasıl ki iletişimin açık yürütülmeyip; arkadan işlerin çevrildiği bir çalışma ortamı söz konusu olursa buna bağılı olarak da kaçınılmaz olarak ÇADG ve bunun bir başka bağlantılı sonucu olan çalışanın örgütüyle olan özdeşleşmesi de azalmaktadır (Balay, 1999:239). Bir başka bakış açısıyla Durdağ ve Naktiyok'un ifadesiyle (2011: 16), çalışma ortamındaki açıklık ve gerekli iyileştirmeler menfaat güden çabaları bir bir ortadan kaldırmakta ve iş göreni kendini politik davranışlara karşı korumaktan uzaklaştırmaktadır. Bu sayede de iş çıktıları da bundan olumlu olarak etkilenmektedir. Gioia vd.'nin de (2000) ifade ettiği üzere ÖÖ, sürekliliği barındıran ve değişime açık bir yapı sergilemektedir. Bu nedenle yukarıda da belirtilmeye çalıştığı gibi araştırmaya konu olan birçok unsur vardır (Oliver ve Roos, 2003: 4).

Yapılan bu kısa açıklamadan hareketle aşağıda $\mathbf{H}_{\mathbf{1}}, \mathbf{H}_{\mathbf{2}}, \mathbf{H}_{\mathbf{3}}$ ve $\mathbf{H}_{\mathbf{4}}$ hipotezleri sunulmaktadır.

$\mathbf{H}_{1}$ : Öğretmenlerin ÖPA'ları, ÖÖ’leri üzerinde negatif yönde anlamlı etki oluşturur.

$\mathbf{H}_{2:}$ Öğretmenlerin ÖPA'ları, ÇADG üzerinde negatif yönde anlamlı etki oluşturur.

$\mathbf{H}_{3}$ : Öğretmenlerin ÇADG düzeyleri, ÖÖ’leri üzerinde pozitif yönde anlamlı etki oluşturur.

$\mathbf{H}_{4}$ : Öğretmenlerin ÇADG, ÖPA'nın ÖÖ’ye etkisinde aracılık etkisi oluşturur.

Araştırmanın amacı dâhilinde kurulan dört hipotez için detaylı analiz yapılarak hipotezler doğrulanmaya çalışımıştır.

\section{3.ÖRNEKLEM VE YÖNTEM}

\subsection{Araştırmanın Amacı ve Kavramsal Modeli}

Çağdaş yönetim anlayışına göre, çalışanların birer makine olmalarının çok ötesinde oldukları kabul görülmekle birlikte; psikolojik ve sosyal anlamda önem taşıdığı da açıktır. Her bir iş görenin hem çalışılan kurum hem de birlikte çalıştığı arkadaşlarına yönelik algı ve tutumlarının birçok unsurla doğrudan ve dolaylı ilişkisi mevcuttur. ÖPA'nın bağımsız değişken olarak belirlendiği bu araştırmada söz konusu algının, öğretmenlerin örgütlerine yönelik özdeşleşme düzeylerine olan etkileri ve bunun yanı sıra oluşan bu etkide ÇADG'nin aracılık etkisinin varlığı sorgulanıp ortaya konulmaya çalışılmaktadır.

Söz konusu bağımlı, bağımsız ve aracı değişken etkilerini içeren bir kavramsal model (Bkz: Şekil 1) oluşturularak değişkenler arasındaki durum daha net olarak ifade edilmeye çalışılmıştır. Alan yazın incelendiğinde; güven kavramının birçok çalışmada ele alınıp incelendiği görülmektedir. Ancak, örgütsel güvenin bir alt boyutu olan ve çalışmamızda doğrudan ilişkili yapıdaki ÇADG kavramının devlet okullarında çalışmakta olan öğretmenlerin çalışma arkadaşlarının politik davranışlarına yönelik algıları ve ÖÖ düzeyleri arasında oluşan etkide aracı olarak rolüne şimdiye kadar değinilmemiştir.

Araştırmanın ana amacı olarak belirlenen ÖPA'ya sahip olan çalışanların ÖÖ’lerinde aracılık oluşturması beklenen ÇADG kavramı önem arz etmektedir. Ayrıca, daha önce böyle bir modelin oluşturulup test edilmemiş olması da araştırmayı özgün kılmaktadır. Yapılan bu çalışma neticesinde elde edilen sonuçların ve yapılan yorumların alan yazın için önemli ve kıymetli katkılar oluşturacağı yönünde beklenti oluşmaktadır. 


\section{Şekil 1: Araştırmanın Kavramsal Modeli}

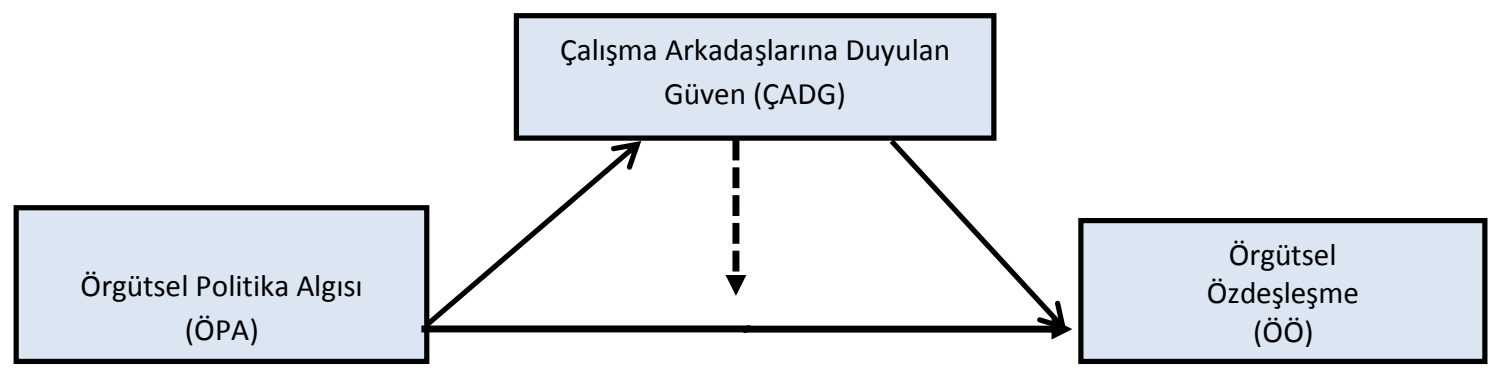

(ÖPA: Örgütsel Politika Algısı, ÇADG: Çalışma Arkadaşlarına Duyulan Güven, ÖÖ: Örgütsel Özdeşleşme)

\subsection{Araştırmanın Evreni ve Örneklemi}

Araştırmada veri toplama aracı olarak tasarlanan anket formunun öğretmenlere uygun hale getirilerek uygulanmaya hazır hale getirilmesinin ardından, araştırma evreninde olan öğretmenlere uygulanabilmesi amacıyla öncelikle üniversite etik kurul onayı alınmıştır. Ardından da İstanbul ì Milli Eğitim Müdürlüğü’ne başvuruda bulunularak, gereken izinler alınıp; iı Milli Eğitim Müdürlüğü ve sorumlu araştırmacı ile karşılıklı protokol imzalanmıştır. Anket formalarının izin kapsamındaki okullarda dağıtılıp toplanması esnasında söz konusu okullara sorumlu araştırmacı tarafından bizzat gidilmiştir. Okul yöneticilerine bakanlığa bağlı il müdürlüğünden alınan izni gösteren onay belgesi teslim edilmiş, anket formundaki ifadelerin genel amacı ve bu ifadelerin cevaplandırılmasında dikkat edilmesi gereken hususlara ilişkin bilgi verilmiştir. Tüm bu bilgi aktarımından sonra anket uygulamaya geçirilmiştir. Okul yönetimine verilen ayrıntılı bilgilerin ardından, öğretmenlere kendilerine verilen anket formunu doldurmadan önce sorumlu araştırmacı tarafından araştırmanın amaçları ve anket formunda yer alan ifadelerin yanıtlanması hususunda bilgi aktarılmıştır. Öğretmenlerin kendilerine teslim edilen anket formundaki ifadeleri içtenlikle ve eksiksiz bir şekilde cevaplandırmalarına imkân sağlamak üzere her bir öğretmene anket formu kapalı zarfla teslim edilmiştir. Öğretmenlerin de doldurulan anket formlarını geri verirken de mutlaka zarfı kapalı şekilde teslim etmeleri kendilerinden rica edilmiştir. Ayrıca, veri toplama araçlarının üzerlerine "not: lütfen ad soyad, telefon, e-mail yazmayınız." araştırmacılarca not düşüldüğü özellikle hatırlatılmıştır. Araştırmanın yalnızca bilimsel amaçlı olması adına yürütülen gizlilik için, katılımcılardan edinilen bilgilerin yalnızca sorumlu araştırmacı tarafından değerlendirip inceleneceği katılımcıların tamamına sözlü ve yazılı olarak ifade edilmiştir. Anket formunun uygulanmasına 2016 yılının Kasım ayında başlanılmış ve 2017 yılının Şubat ayında tamamlanmıştır.

Araştırmada, 2016-2017 eğitim öğretim yılının güncel bilgilerine bağlı olmak üzere İstanbul î Milli Eğitim Müdürlüğü’nden edinilen bilgiler dâhilinde İstanbul'un Kadıköy îlçesi'nde eğitim veren 90 devlet okulunda çalışmakta olan 3099 öğretmen çalışma evreni olarak belirlenmiştir. Anket uygulanacak örnek kitlesinin büyüklüğünü belirlemek için, aşağıdaki örnek büyüklüğü eşitliğinden yararlanılmıştır.

$\mathrm{n}=\mathrm{n}_{0} /\left(1+\mathrm{n}_{\mathrm{o}} / \mathrm{N}\right), \mathrm{n}_{\mathrm{o}}=\left(\mathrm{t}^{2} \mathrm{xs} \mathrm{s}^{2}\right) / \mathrm{d}^{2}$

Bu formüllerdeki N: evren büyüklüğü, n: örneklem büyüklüğü, t: güven düzeyine karşlık gelen tablo z değeri $(0.05$ için 1,96 , 0.01 için 2,58 ve 0.001 için 3,28), s: evren için tahmin edilen standart sapma ve d: kabul sapma toleransını ifade etmektedir (Bartlett, vd. 2001: 46).

$$
\begin{aligned}
& n_{0}=\left(1,96^{2} \times 0,5^{2}\right) / 0,05^{2}=384,16 \\
& n=384,16 /(1+384,16 / 3099)=341,16
\end{aligned}
$$

Yukarıda verilen oransal ifadeler ve ana kütlenin 3099 olduğu bilgisine dayanarak ana kütleyi temsil edecek minimum örneklem büyüklüğü 341,16 olarak hesaplanmıştır. Örneklemse rastgele yöntem olarak ifade edilen evren büyüklüğünü temsil eden bir örneklemin seçilmesiyle evren için genelleme yapmaya imkân veren (Creswell, 2014: 158) random yöntemle belirlenmiştir. Yapılan bu çalışma ise 405 öğretmenin katıımıyla gerçekleştirilmiştir.

\subsection{Veri Toplama Araçları}

Araştırmaya ilişkin olarak üç farklı değişken belirlenmiştir. Değişkenleri ölçümlemek için tercih edilen ölçekler, daha önceki çalışmalarda faktör analizine tabi tutulup geçerlilik ve güvenilirlikleri test edilip doğrulanmış olan ölçeklerdir. Kullanılan ölçeklerde geçerlilik doğrulaması yapabilmek amacıyla açıklayıcı ve doğrulayıcı olmak üzere iki tür faktör analizi gerçekleştirilmiştir. Bunun yanı sıra, 50 örneklem üzerinde pilot çalışma yapılarak anket formundaki ifadelerin anlaşılmasında herhangi bir sorun olup olmadığı tespit edilmeye çalışıımıştır. Yapılan pilot çalışma yardımıyla ifadelerin anlaşılmasında hiçbir sorun olmadığı görülmüştür. 
Anket formu dört farklı bölümden oluşmaktadır. illk bölümde ÖPA'yı ölçümleyebilmek amacıyla Hochwarter vd. (2003) tarafından geliştirilip, Türkçe'ye uyarlanması Akdoğan ve Demirtaş (2014) tarafından yapılan altı ifade ve tek boyuttan oluşan "Örgütsel Politika Algısı Ölçeği” kullanılmıştır. Ilgili ölçekte yer alan ifadelerin ölçülmesinde 5'li Likert Ölçekleme (1: Kesinlikle Katılmıyorum, ......, 5: Kesinlikle Katılıyorum) tercih edilmiştir. Yapılan analizler yardımıyla elde edilen sonuçlara bakıldığında; ölçekten hiçbir ifade çıkartılmamıştır. Açıklayıcı faktör analizi neticesinde tek faktörlü yapı korunarak, bu tek faktörün toplam varyansta $\% 75,836^{\prime}$ Iık açıklayıcı olduğu görülmektedir. Araştırma verileri için betimleyici faktör analizini uygulamayı mümkün kılan KMO (Kaise-Meyer-Olkin Measure of Sampling Adequacy) örneklem yeterliliği 0,898 ve bu data setinden anlamlı faktörler oluşabileceğini ifade eden evrensellik ölçütü (Bartlett's Test of Sphericity; 2070,017, $p<0,000$ ) yeterlilik göstermektedir. Tek faktörlü yapının faktör yüklemeleri aşağıdaki tabloda (Tablo 1) ifade edilmiştir.

Tablo 1: Örgütsel Politika Algısı Ölçeğine Illişkin Faktör Yükleri

\begin{tabular}{|c|c|}
\hline Örgütsel Politika Algısı (ÖPA) & Boyutlar \\
\hline Madde & ÖPA \\
\hline $\begin{array}{l}\text { ÖPA3."Bu okulda çalışanlar, kendilerine yardımı dokunacak kişilere yaranmak için çok fazla zaman } \\
\text { harcarlar." }\end{array}$ & 0,919 \\
\hline ÖPA4. "Bu okulda çalışanlar, çıkar pastasından kendi paylarını almak için arka planda işler çevirirler." & 0,904 \\
\hline $\begin{array}{l}\text { ÖPA6."Bu okulda çalışanlar başkalarından daha iyi görünmek uğruna birbirlerinin açıklarını ortaya } \\
\text { çıkarırlar." }\end{array}$ & 0,868 \\
\hline ÖPA1."Bu okulda bireysel çıkarlara hizmet eden davranışlar çok fazladır." & 0,867 \\
\hline ÖPA2. “Bu okulda çalışanlar, işyeri çıkarlarından daha çok kendi çıkarlarını düşünürler.” & 0,851 \\
\hline ÖPA5.“Bu okulda çalışanlar, işyerinde var olan gruplara girme yönünde eğilim gösterirler.” & 0,812 \\
\hline Cronbach's Alpha $(\alpha)$ & $\% 93,6$ \\
\hline Açıklanan Toplam Varyans & $\% 75,836$ \\
\hline KMO & 0,898 \\
\hline Ölçek Ortalaması & 2,60 \\
\hline
\end{tabular}

Tablo 1'de belirtildiği gibi, ÖPA ölçeğindeki ifadeler için yapılan faktör analizi sonuçlarına göre; altı ifadeden oluşan "Örgütsel Politika Algısı Ölçeği "'nden hiçbir ifade analiz dışında bırakılmamıştır. Faktör yüklemeleri ise en düşük $(0,812)$ faktör yüküyle "Bu okulda çalışanlar, işyerinde var olan gruplara girme yönünde eğilim gösterirler." ifadesinde yer almaktadır. Ölçeğe dair en yüksek yükleme değeri olan ifade ise $(0,919)$ faktör yüküyle "Bu okulda çalışanlar, kendilerine yardımı dokunacak kişilere yaranmak için çok fazla zaman harcarlar." ifadesidir. Ölçeğin ortalaması ise 2,60 olarak bulunmuştur. Yapılan açıklayıcı faktör analizi sonrasında AMOS istatistik paket programı marifetiyle doğrulayıc faktör analizi (DFA) yapılmıştır. Yapılan faktör analiziyle her bir ifadenin faktör yüklemelerinin uygun sınırlarda yer aldığı görülmüş ve yine hiçbir ifade analiz dışına alınmamıştır. Yapılan DFA sonucunda modelin uyum indekslerine bakıldığında kabul edilebilir uyum aralığında yer aldığı görülmektedir $\left(\Delta \chi^{2} / s d=3,350, \mathrm{GFI}=0,982, \mathrm{CFI}=0,992, \mathrm{IFI}=0,992, \mathrm{NFI}=0,989, \mathrm{RMR}=0,017, \mathrm{RMSEA}=0,076\right)$.

Anket formunun ikinci bölümünde yer alan ölçek ise; ÇADG'yi ölçmeye yarar sağlamaktadır. ilgili ölçek, Daboval, Comish ve Swindle ve Gaster'in (1994) 22 ifade ve üç alt boyuttan oluşan örgütsel güven ölçeğinin bir alt boyutunda yer alan "Çalışma Arkadaşlarına Duyulan Güven Ölçeği” ile ölçülmüştür. Ölçek Türkçe'ye Kamer (2001) tarafından uyarlanmış ve Yılmaz'ın (2005) yaptığı çalışmayla okullarda uygulanmaya imkân verilmiştir. Tek boyut ve sekiz ifadeden oluşan ölçek için ÇAG4 ("Çalışma arkadaşlarım politik (içten pazarlıklı) davranışlar sergilemezler.") ve ÇAG8 ("Çalışma arkadaşlarım işyerindeki kuralları istismar etmezler.") ifadeleri olumsuz anlam taşımaları nedeniyle ters kodlanarak yine 5'li Likert Tipi Ölçekleme kullanılarak (5: Kesinlikle Katılmıyorum, ..., 1: Kesinlikle Katılıyorum) analize dahil edilmişlerdir. Yapılan analizler neticesinde sekiz ifadeden hiçbiri analiz dışında bırakılmamıştır. SPSS istatistik paket programı yardımıyla yapılan açıklayıcı faktör analizi sonuçlarının yer aldığı tablo aşağıda belirtilmeye çalışılmıştır.

Tablo 2: Çalışma Arkadaşlarına Duyulan Güvene İlişkin Faktör Yükleri

\begin{tabular}{|l|c|}
\hline \multicolumn{1}{|c|}{ Çalışma Arkadaşlarına Duyulan Güven (ÇADG) } & Boyutlar \\
\hline Madde & $\mathbf{0 , 8 7 1}$ \\
\hline ÇAG3.“Çalışma arkadaşlarım dürüst ve açıktırlar.” & $\mathbf{0 , 8 6 3}$ \\
\hline ÇAG6."Çalışma arkadaşlarım uyumludurlar.” & $\mathbf{0 , 8 6 3}$ \\
\hline ÇAG7."Çalışma arkadaşlarımın arasındaki güven düzeyi çok yüksektir.” & $\mathbf{0 , 8 5 5}$ \\
\hline ÇAG5.“Çalışma arkadaşlarım mesleki becerileri oldukça yüksektir.” & $\mathbf{0 , 8 5 0}$ \\
\hline ÇAG2."Çalışma arkadaşlarım sorumluluk sahibidirler.” & $\mathbf{0 , 8 3 5}$ \\
\hline ÇAG8."Çalışma arkadaşlarım işyerindeki kuralları istismar etmezler.” & $\mathbf{0 , 8 1 6}$ \\
\hline ÇAG4. “Çalışma arkadaşlarım politik (içten pazarlıkı) davranışlar sergilemezler.” & $\mathbf{0 , 7 8 4}$ \\
\hline ÇAG1."Çalışma arkadaşlarım her türlü zorlukta bana yardım ederler.” & \\
\hline
\end{tabular}




\begin{tabular}{|r|r|}
\hline Cronbach's Alpha ( $\alpha$ ) & $\% 94,1$ \\
\hline Açıklanan Toplam Varyans & $\% 70,977$ \\
\hline KMO & 0,930 \\
\hline
\end{tabular}

Tablo 2 incelendiğinde; ÇADG ölçeğindeki ifadeler için yapılan faktör analizi sonuçlarında sekiz ifadenin faktör yüklemelerinin oldukça yüksek değerlerde yüklendiği rahatlıkla görülmektedir. Faktör yüklemelerinden en düşük yüklemeye sahip olan ifade $(0,784)$ faktör yüküyle "Çalışma arkadaşlarım her türlü zorlukta bana yardım ederler." ifadesiyken; en yüksek yükleme değeri olan $(0,871)$ faktör yüküyle "Çalışma arkadaşlarım dürüst ve açıktırlar." ifadesindedir. Ayrıca, KMO= 0,930 değeri, ilgili ölçeğin faktör analizi uygulamak için yeterliliği ve uygunluğunu ortaya koymaktadır. Bir diğer test sonucu, anlamlı faktör elde edebilmek üzere küresellik ölçütü olan $x^{2}$ Bartlett's test (28) sonucu= 2575,982, p<0,000 değerleri de uygunluk göstermektedir. Ölçek tarafından açıklanan toplam varyans \%70,977'dir. Bunun yanı sıra ölçeğin ortalaması ise 3,84 olarak bulunmuştur. Yapılan açıklayıı faktör analizi sonrasında AMOS programı yardımıyla gerçekleştirilen DFA ile ilgili ölçek doğrulanmaya çalışılmıştır. Ölçeğin uyum indekslerine bakıldığında; ölçeğin kabul edilebilir mükemmel uyum aralığında yer aldığı görülmektedir $\left(\Delta \chi^{2} / s d=1,332, \mathrm{GFI}=0,989, \mathrm{CFI}=0,998, \mathrm{IFI}=0,998, \mathrm{NFI}=0,993, \mathrm{RMR}=0,010, \mathrm{RMSEA}=0,029\right)$.

Anket formundaki üçüncü bölümde yer alan ÖÖ değişkenini ölçümlemek üzere Mael ve Ashforth (1992) tarafından geliştirilen ve Türkçe'ye uyarlaması Tak ve Aydemir (2004) tarafından yapılan altı ifadeden oluşan tek boyutlu "Örgütsel Özdeşleşme Ölçeği" kullanılmıştır. Tıpkı anket formunda yer alan diğer iki ölçekte olduğu gibi bu ölçek için de iki farklı faktör analizi gerçekleştirilmiş. Yapılan açıklayııı faktör analizi sonucunda elde edilen faktör yüküne ilişkin sonuçlar aşağıda Tablo 3'te yer almaktadır.

Tablo 3: Örgütsel Özdeşleşmeye iliş̧kin Faktör Yükleri

\begin{tabular}{|c|c|}
\hline Örgütsel Özdeşleşme (ÖÖ) & Boyutlar \\
\hline Madde & ÖÖ \\
\hline $\begin{array}{l}\text { ÖÖ5."Başka biri çalıştığım okuldan övgüyle bahsettiğinde, bunu şahsıma yönelik yapıımış bir övgü, } \\
\text { iltifat olarak kabul ederim." }\end{array}$ & 0,872 \\
\hline Öö4. “Çalıştığım okulun başarılarını kişisel başarım olarak kabul ederim.” & 0,859 \\
\hline Öö2."Başka insanların çalıştığım okul hakkında ne düşündüklerini çok fazla önemserim.” & 0,851 \\
\hline Öö3.“Çalıştığım okuldan bahsederken; "onlar" yerine "biz" ifadesini kullanırım." & 0,840 \\
\hline $\begin{array}{l}\text { ÖÖ1."Başka biri çalışı̆̆ım okulu eleştirdiğinde, bunu şahsıma yönelik yapıılmış olumsuz bir eleştiri, } \\
\text { hakaret olarak algılarım.” }\end{array}$ & 0,820 \\
\hline $\begin{array}{l}\text { ÖÖ6. "Eğer, medyada çalıştığım okul hakkında olumsuz yönde eleştirel bir haber çıkmışsa (çıkarsa) } \\
\text { bundan rahatsızıı hisseder; utanç duyarım.” }\end{array}$ & 0,773 \\
\hline Cronbach's Alpha ( $\alpha)$ & \%91,4 \\
\hline Açıklanan Toplam Varyans & $\% 69,977$ \\
\hline KMO & 0,930 \\
\hline Ölçek Ortalaması & 3,45 \\
\hline
\end{tabular}

Tablo 3 incelendiğinde; ilgili ölçek için yapılan güvenilirlik analizi sonucu 0,914 olarak bulgulanırken; faktör analizi sonucunda faktör yüklemelerinin $0,40^{\prime} ı$ üzerinde olduğu görülmektedir. Faktör yüklemelerine bakıldığında en yüksek yüklemenin $(0,872)$ "Başka biri çalıştığım okuldan övgüyle bahsettiğinde, bunu şahsıma yönelik yapılmış bir övgü, iltifat olarak kabul ederim." ifadesinde yer aldığı bulgulanmıştır. En düşük yüklemenin $(0,773)$ ise; "Eğer, medyada çalıştığım okul hakkında olumsuz yönde eleştirel bir haber çıkmışsa (çıkarsa) bundan rahatsızlık hisseder; utanç duyarım." ifadesinde olduğu görülmektedir. Ölçeğin toplam varyanstaki açıklama gücünün \%69,977 ve ortalamasının da 3,45 olduğu tespit edilmiştir. illgili ölçeğin faktör analizi için uygunluğunu KMO değeri $(0,930)$ doğrularken; anlamlı faktör yükleri elde etmek için gerekli olan küresellik ölçütü olan $x^{2}$ Bartlett's test (15) sonucu= $1592,953, p<0,000$ olarak bulunmuştur. Bunların yanı sıra Örgütsel Özdeşleşme Ölçeği DFA modeli uyum indekslerine bakıldığında kabul edilebilir mükemmel uyum aralığında yer aldığı görülmektedir $\left(\Delta \chi^{2} / s d=2,160, \mathrm{GFI}=0,989, \mathrm{CFI}=0,996, \mathrm{IFI}=0,996, \mathrm{NFI}=0,992, \mathrm{RMR}=0,017, \mathrm{RMSEA}=0,054\right)$.

\section{BULGULAR}

\subsection{Katılımcıların Demografik Özellikleri}

Araştırmaya, İstanbul i̇li Kadıköy İlçesi'ndeki devlet okullarında çalışan 405 öğretmen katılmıştır. 405 öğretmenin medeni durumu, cinsiyeti, yaşı, öğrenim düzeyi, haftalık ders yükü, birlikte çalıştığı öğretmen sayısı, çalışılan okuldaki görev süresi eğitim sektöründeki toplam hizmet süresiyle ilgili elde edilen verilerin dağılımını elde etmek için tanımlayıcı analizler yapılmıştır. Yapılan analizlerde elde edilen sonuçlara dayalı olarak hazırlanan tablo (Tablo 4) aşağıda sunulmaktadır. 
Tablo 4: Demografik Değişkenlere Ait Analizler (n: 405)

\begin{tabular}{|c|c|c|c|}
\hline \multirow{2}{*}{\multicolumn{2}{|c|}{ Demografik Değişkenler }} & \multicolumn{2}{|c|}{ Devlet Okulu } \\
\hline & & \multirow{2}{*}{$\begin{array}{c}\text { Sayı (n) } \\
85 \\
171 \\
105 \\
38 \\
6 \\
\end{array}$} & \multirow{2}{*}{$\begin{array}{c}\text { Yüzde (\%) } \\
21,0 \\
42,2 \\
25,92 \\
9,4 \\
1,5 \\
\end{array}$} \\
\hline Yaş & $\begin{array}{l}18-29 \text { yaş } \\
30-39 \text { yaş } \\
40-49 \text { yaş } \\
50-59 \text { yaş } \\
60 \text { ve üzeri yaş }\end{array}$ & & \\
\hline Cinsiyet & $\begin{array}{l}\text { Kadın } \\
\text { Erkek }\end{array}$ & $\begin{array}{l}221 \\
184\end{array}$ & $\begin{array}{l}54,6 \\
45,4\end{array}$ \\
\hline Medeni Hal & $\begin{array}{l}\text { Evli } \\
\text { Bekâr }\end{array}$ & $\begin{array}{l}243 \\
162\end{array}$ & $\begin{array}{l}60,0 \\
40,0\end{array}$ \\
\hline Eğitim Düzeyi & $\begin{array}{l}\text { Lise } \\
\text { Üniversite } \\
\text { Yüksek Lisans } \\
\text { Doktora }\end{array}$ & $\begin{array}{c}96 \\
268 \\
40 \\
1\end{array}$ & $\begin{array}{c}23,7 \\
66,2 \\
9,9 \\
0,2\end{array}$ \\
\hline Haftalık Ders Yükü & $\begin{array}{l}1-15 \text { saat } \\
16-32 \text { saat } \\
33-49 \text { saat } \\
50 \text { saat ve üzeri }\end{array}$ & $\begin{array}{c}35 \\
312 \\
42 \\
16\end{array}$ & $\begin{array}{c}8,6 \\
77,0 \\
10,4 \\
4,0\end{array}$ \\
\hline $\begin{array}{l}\text { Birlikte çalışılan personel } \\
\text { sayısı }\end{array}$ & $\begin{array}{l}\text { 1-10 öğretmen } \\
11-25 \text { öğretmen } \\
26 \text { öğretmen ve üzeri }\end{array}$ & $\begin{array}{c}19 \\
129 \\
257\end{array}$ & $\begin{array}{c}4,7 \\
31,9 \\
63,5\end{array}$ \\
\hline $\begin{array}{l}\text { Bu Okuldaki Hizmet } \\
\text { Süresi }\end{array}$ & $\begin{array}{l}1 \text { yıldan az } \\
1-5 \text { yıl } \\
6-10 \text { yıl } \\
11-15 \text { yıl } \\
16-20 \text { yıl } \\
21 \text { yıl ve üzeri }\end{array}$ & $\begin{array}{c}87 \\
217 \\
62 \\
13 \\
18 \\
8\end{array}$ & $\begin{array}{c}21,5 \\
53,6 \\
15,3 \\
3,2 \\
4,4 \\
2,0\end{array}$ \\
\hline $\begin{array}{l}\text { Eğitim Sektöründeki } \\
\text { Toplam Hizmet Süresi }\end{array}$ & $\begin{array}{l}1-5 \text { yıl } \\
6-10 \text { yıl } \\
11-15 \text { yıl } \\
16-20 \text { yıl } \\
21 \text { yıl ve üzeri }\end{array}$ & $\begin{array}{c}177 \\
105 \\
50 \\
36 \\
37\end{array}$ & $\begin{array}{c}43,7 \\
25,9 \\
12,3 \\
8,9 \\
9,1\end{array}$ \\
\hline & TOPLAM & 405 & $\% 100$ \\
\hline & GENEL TOPLAM & & \\
\hline
\end{tabular}

Tablo 4 incelendiğinde; araştırmanın örneklemini oluşturan 405 öğretmene ait demografik özelliklere ilişkin bilgilerin sunulduğu görülmektedir. Illgili tabloda yer alan sonuçlara göre; 405 öğretmenin yaş dağılımına bakıldığında en genç öğretmenin 25 yaşında, en yaşlı öğretmenin ise 60 yaşında olduğu bulgulanmıştır. Ayrıca, öğretmenlerin ortalama yaşının 37,74 (Std. Sap.: 9,295) olduğu görülmektedir. Öte yandan yaş aralıklarına bakıldığında 171 öğretmenin 30-39 yaş aralığında yer aldığı (\%42,2); onu takip eden yaş dağıımının da 40-49 yaş aralığında olan 105 öğretmenden $(\% 32,59)$ oluşturulduğu bulgulanmıştır. Araştırmaya katılım gösteren öğretmenlerin cinsiyet dağılımlarıysa; birbirine oldukça yakın değerler olmakla birlikte 405 öğretmenden 221'inin (\%54,6) kadın; 184 öğretmenin de erkek $(\% 45,4)$ olarak dağıldığını göstermektedir. Medeni durumlarındaysa; evli olan öğretmenlerin çoğunluğu oluşturduğu (\%60) bulgulanmıştır. Öğretmenlerin eğitim düzeylerinin incelenmesi sonucunda, lise ile doktora düzeyinde eğitime sahip oldukları görülmektedir. 268 öğretmenin $(\% 66,2)$ üniversite eğitimini tamamladığı belirtilmiştir. Kurumda çalışan toplam öğretmen sayılarında dağılımın üç farklı kategoride toplanmaya çalışıldığı ve sonuçlara göre de çalışma ortamında 26 öğretmen ve üzeri $(\% 63,5)$ sayıda öğretmenin çoğunlukta olduğu görülmektedir. Onu takip edenin ise; 129 öğretmenin; çalıştığı okulda 11-25 öğretmenin birlikte (\%31,9) çalıştığıdır. Haftalık ders yükü (saat) dağılımındaysa dört farklı kategorinin belirlenip; 312 öğretmenin haftalık ders yükünün 16-32 saat (\%77) aralığında yer aldığı bulgulanmıştır.

\subsection{Korelâsyon Analizleri}

Yapılan korelasyon analizleri sonucuna göre değişkenler arasında istatistiksel olarak anlamlı ilişkiler tespit edilmiştir. ÖPA, ÇADG ve ÖÖ’nün 0,001 düzeyinde ilişkili olduğu ortaya çıkmıştır. Elde edilen bulgulara göre değişkenlerden ÖPA ile ÇADG arasında, ÖPA ile ÖÖ arasında negatif yönlü ve son olarak ÇADG ile ÖÖ arasında pozitif yönlü bir ilişkinin varlığı mevcuttur. 
Yani, ÖÖ’nün çalışanlar tarafından sergilenmesinde ÖPA ve ÇADG'nin yönlü etkisi vardır. Bahsi geçen bu üç değişkene ait ölçek ortalamaları ve standart sapma değerleri de hesaplanmış, Cronbach's Alpha değerleriyle birlikte Tablo 6'da sunulmuştur.

Tablo 5: Değişkenlere Ait Ortalama, Standart Sapma ve Korelasyon Katsayıları ( $n: 405)$

\begin{tabular}{|l|l|l|l|l|l|}
\hline Değişkenler & Ort. & S. S. & $\mathbf{1}$ & $\mathbf{2}$ & $\mathbf{3}$ \\
\hline 1. ÖPA & 2,6027 & 0,9779 & $0,936^{\text {a }}$ & & \\
\hline 2. ÇADG & 3,8354 & 0,7829 & $-0,441^{* *}$ & $0,941^{\text {a }}$ & \\
\hline 3. ÖÖ & 3,4470 & 0,9522 & $-0,166^{* *}$ & $0,203^{* *}$ & $0,914^{\text {a }}$ \\
\hline
\end{tabular}

**Korelasyon 0,01 düzeyinde anlamlıdır. $\left({ }^{* *} p<0,01\right)^{a}$ Değişkenin içsel güvenirlik katsayı (Cronbach's alpha).

Tablo 5 incelendiğinde; değişkenler arasındaki ilişkilerin anlamlı düzeyde ilişkiler olduğu görülmektedir.

\subsection{Yol Analizleri}

ÖPA'nın ÖÖ üzerinde olan etkisinde ÇADG'nin aracılık etkisini test edebilmek için Baron ve Kenny (1986) tarafından öne sürülen yaklaşım çerçevesinde hareket edilmektedir. Bu nedenle, aracılık etkisinin test dilebilmesi için bazı gerek şartlar mevcuttur. Bu gerek şartlardan, öncelikle bağımsız değişkenin (ÖPA) bağımlı değişken (ÖÖ) üzerinde istatistiki düzeyde anlamlı etkisinin olması gerekmektedir. Gerek şartlardan ikincisi olarak, yine bağımsız değişkenin (ÖPA) aracı değişken (ÇADG) üzerinde anlamlı bir etki oluşturması muhakkaktır. Bir diğer gerek şart ise; aracı değişkenin (ÇADG) bağımlı değişken (ÖÖ) üzerinde oluşturacağı etkinin de anlamlı olmasıdır. Dördüncü ve son şart da aracı değişkenin (ÇADG) bağımsız değişken (ÖPA) ile beraber modele dâhil edilmesi sonucunda bağımsız değişkenin (ÖPA) bağımlı değişken (ÖÖ) üzerindeki etkisi düşerken, aracı değişkenin de (ÇADG) bağımlı değişken (ÖÖ) üzerinde anlamlı bir etkisinin olması gerekmektedir (Meydan ve Şeşen, 2011: 130).

Yukarıda ifade edilen gerek şartları tek tek ele alabilmek amacıyla sırasıyla aşağıdaki adımlar test edilmiştir. Öncelikle, bağımsız değişken olan ÖPA'nın bağımlı değişken olan ÖÖ üzerindeki etkisinin varlığı sorgulanmaya çalışılmıştır. illgili sorgulama için yapısal regresyon modeli oluşturulmuştur. Oluşturulan modelin sonuçlarına bakıldığında ÖPA'dan ÖÖ’ye olan regresyon yolunun (Standardize $\beta$ : $-0,173$, Standart hata: 0,053, p: 0,001) anlamlı olduğu görülmektedir. Illk adıma ilişkin sonuçlar incelendiğinde modelin uyum indekslerinin $\left(\Delta \chi^{2} / s d=1,639, G F I=0,969, \quad C F I=0,992, \quad I F I=0,992, N F I=0,979\right.$, $\mathrm{RMR}=0,034$, RMSEA $=0,040$ ) kabul edilebilir sınırlarda olduğu bulgulanmıştır. Böylece, aracılık etkisinin testi için gerekli olan ilk şart yerine getirilmiştir.

illk gerekliliğin yerine getirilmesinin ardından ikinci gerek şartı doğrulamak amacıyla kurulan yapısal regresyon model ile bağımsız değişken olan ÖPA'nın aracı değişken olan ÇADG üzerindeki etkisinin varlığı sorgulanmıştır. Kurulan ikinci model sonucuna bakıldığında; oluşturulan modele dair uyum indeksleri $\left(\Delta \chi^{2} / s d=1,791, G F I=0,960, C F I=0,989, \quad I F I=0,989\right.$, $\mathrm{NFI}=0,975, \mathrm{RMR}=0,035$, RMSEA=0,044) kurulan modelin geçerliliğini ve analiz için toplanan verinin de model için uyumluluğunu doğrulamaktadır. Ayrıca, ilgili analiz sonucu elde edilen bulgulara (ÖPA $\rightarrow$ ÇADG, Standardize $\beta:-0,32$, Standart hata: 0,036, p: 0,000) bakıldığında; aracılık etkisinin test edilmesindeki ikinci adımın da uygunluğu kabul edilmektedir. ÖPA'nın, ÇADG üzerinde anlamlı etki oluşturarak kurulan modelin istatistiksel olarak anlamlı olduğunu göstermektedir. Böylece aracılık etkisinin test edilebilmesi için gerek şartlardan ikincisi de doğrulanmaktadır.

Aracılık etkisinin ortaya konulması için gereken üçüncü şartın test edilmesi için bu sefer de aracı değişken olan ÇADG'nin bağımlı değişken olan ÖÖ üzerindeki etkisine bakılmak üzere bir regresyon modeli geliştirilmiştir. İlgili model sonuçlarına göre modelin uyum indeks değerlerinin $\left(\Delta \chi^{2} / s d=1,627, G F I=0,964, C F I=0,990, \quad I F I=0,990, N F I=0,975, R M R=0,031\right.$, RMSEA $=0,039$ ) neticesinde kurulan modelin ve veri setinin modelle olan uyumluluğunu ortaya koyduğu görülmektedir. Bunun yanı sıra, yapılan yol analizi sonucunda (ÇADG $\rightarrow$ ÖÖ, Standardize $\beta: 0,275$, Standart hata: 0,066, p: 0,000) üçüncü adımın da aracılık etkisinin test edilmesi için doğrulandığı görülmektedir.

Aracılık etkisinin test edilebilmesi için son adım olan ÖPA'nın ÖÖ üzerindeki etkisi ve bu etkide ÇADG'nin aracı etkisi için bir yol analizi modeli kurulmuştur. Bu modeli kurup test edebilmek için gerekli olan ilk üç adım doğrulanmıştır. Kurulan yol analizi sonucunda elde edilen bulgular Şekil 2'de ifade edilmeye çalışılmıştır. 


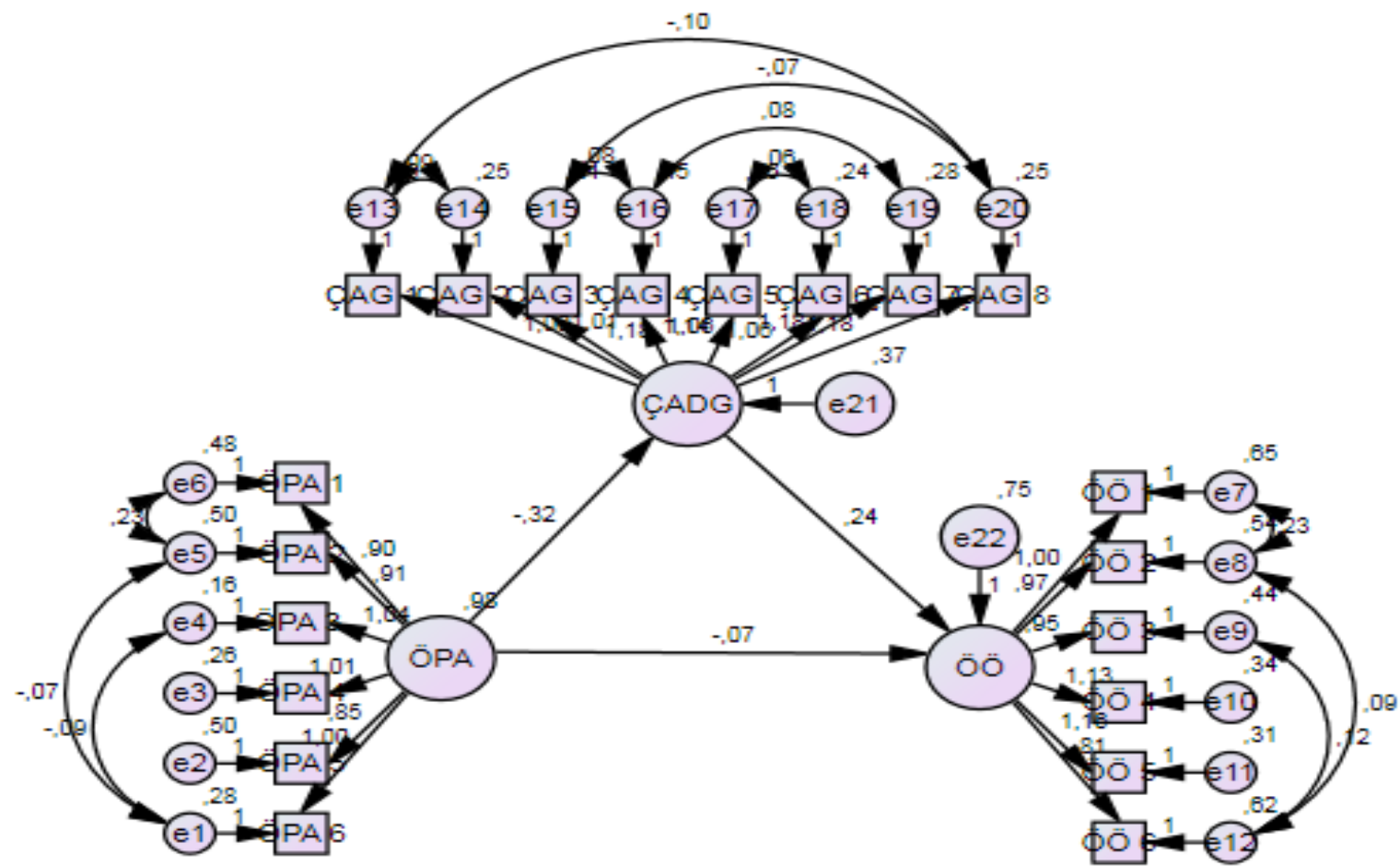

Şekil 2'ye bakıldığında ilk başta belirtilen aracılık analizi gerekliliklerinden ilk üçünün yerine getirildiği açıkça görülmektedir. Ardından, araştırmanın kavramsal modelinde aracı değişken olarak belirlenen ÇADG modele dâhil edilmiştir. Bağımsız değişken olan ÖPA'nın bağımlı değişken konumundaki ÖÖ üzerindeki anlamlı etkisinin ilk durumdaki etkisine (Standardize $\beta$ : $-0,173$, Standart hata: 0,053 , p: 0,001) kıyasla büyük oranda azaldığı ve hatta anlamlılı̆ını (Standardize $\beta:-0,073$, Standart hata: 0,053, p: 0,173) yitirdiği bulgulanmıştır. Öte yandan; ÇADG 'nin ÖÖ üzerindeki anlamlı etkisinin (Standardize $\beta: 0,275$, Standart hata: $0,066, p: 0,000$ ) bağımsız değişken olan ÖPA değişkeniyle birlikte modele dâhil edilmesinden sonra da (Standardize $\beta: 0,242$, Standart hata: 0,079, p: 0,002) devam ettiği tespit edilmiştir. Elde edilen bu sonuçlar ışığında bağımsız değişken olan ÖPA'yla beraber modele dâhil edilen aracı değişken olan ÇADG'nin tam aracılık etkisi oluşturduğu rahatlıkla ifade edilebilmektedir.

Ayrıca, aracılık etkisinin test edilebilmesi için oluşturulan regresyon modelinin uyum indeksleri de $\left(\Delta \chi^{2} / \mathrm{sd}=1,703\right.$, $\mathrm{GFI}=0,939, \mathrm{CFI}=0,983, \mathrm{IFI}=0,983, \mathrm{NFI}=0,960, \mathrm{RMR}=0,039, \mathrm{RMSEA}=0,042$ ) ilgili modeli mükemmel uyum aralığında olduğunu belirterek doğrular niteliktedir.

Baron ve Kenny'nin (1986) ortaya koyduğu aracılık testi tekniğiyle gerekli analizler gerçekleştirilmiştir. Bu noktadan sonra yapılan en son işlemse; gerçekleşen bu değişimin anlamlı olup olmadığını test edebilmek amacıyla alan yazında gerekliliği vurgulanan testi yapabilmektir ve buradan elde edilecek olan t değerinin anlamlılığına bakabilmektir (Sobel, 1982). Bunun için gerekli olan test etme yöntemi ise Sobel Testi'dir. Sobel testi, "kısmi veya tam aracılığın oluşmasında, bağımsız değiş̧ken tarafından açıklanan varyanstaki azalmanın anlamlılığını ölçen bir yöntemdir "(Sobel, 1982). Testin mantığı gereği, kurulan kavramsal modele bağlı kalarak modeldeki değişkenlerin regresyon ağırlıklarıyla ilgili aralarında oluşan ilişkilere dair standart hataları hesaba katabilmektir. Böylece, regresyon katsayılarındaki değişimin anlamlılık düzeyi kolaylıkla test edilebilmektedir.

Yapılan Sobel testi sonucunda, t değeri $(-4,37)$ olarak bulunmuş, $p$ değerinin de 0,01 'den daha küçük olduğu görülmüştür. Dolayısıyla, ÇADG'nin modele ilave edilmesiyle birlikte, ÖPA ile ÖÖ arasındaki ilişkinin anlamlı olarak azaldığı (hatta ortadan kalktığı), bir başka deyişle ÇADG'nin ara değişken etkisinin anlamlı olduğu desteklenmiştir.

\section{SONUÇ VE TARTIŞMA}

Toplumsal gelişme ve topluma fayda sağlamak üzere birçok meslek grubu (doktor, avukat, mühendis, akademisyen, hemşire, vd.) öne çıkmaktadır. Belki de en fazla manevi duygular barındıran mesleklerden biri de öğretmenliktir. Bir üyesi olarak yer aldığı ve doğrudan etkileşim içerisinde olduğu toplumdaki insanlara bir şey katabilmek amacı güden öğretmenler, 
yoğun çalışma koşullarına sahiptirler. Özellikle ülkemizin ekonomik ve sosyal şartlarını ele almamız durumunda daimî anlamda meslek sahibi olabilmenin zorluğu açıktır. Daha da ötesi kamu kurum ve kuruluşlarında önemli sorumluluklar üstlenerek memur sıfatıyla çalışan iş görenlerin yaşadığı süreç kuşkusuz ki çok daha zorludur. Her ne kadar zor bir çalışma ortamına sahip olunulsa da mevcut koşullar gereği karşılaşılan zorluklarla mücadele etme ve işten ayrılma niyetinin olabildiğince düşük seviyede tutulacağı tahmin edilmektedir. Ayrıca, yaşanan durum veya karşılaşılan olumsuz şartlar ne olursa olsun sahip olduğu özellikler nedeniyle ülke savunması ve güvenliğini sağlayan askeri personel ve polisler, adalet sağlayıcı hukukçular, insan sağlığını her şeyden önemli gören doktorlar, eğitimin öneminin yadsınamaz bir gerçek olduğunu çok iyi özümsemiş olan öğretmenler gibi; temelinde hizmet sağlama olan maneviyatı yüksek düzeydeki meslek gruplarının örgütsel anlamda yüksek özdeşleme yaşamaları beklenmektedir. Bu nedenle bu ve benzeri iş görenlerin yoğun emek vererek edindikleri mesleklerine bağlı oldukları ve bu sayede de kurumlarıyla bu bağlılıklarını özdeşleştirdikleri rahatlıkla düşünülebilir.

Meslek yapısı gereği yüksek eğitim seviyesi gerektiren öğretmenlik mesleğini icra eden ve araştırmaya katılan 405 öğretmenin de \%66,2'sinin üniversite eğitimini tamamladığı görülmektedir. Devlet okullarında yürütülen bu araştırmada ağırlıklı olarak katılımcıların 30-39 yaş aralı̆̆ında yer aldığı görülmüştür. Ayrıca, belirlenen sınırlarda mesai yaptıkları da kendi ifadeleriyle belirtilerek ortaya konulmuştur (16-32 saat haftalık ders yükü). Genel dağılıma bakıldığında öğretmenlerin 26 öğretmen ve üzeri iş görenle birlikte çalıştığı görülmektedir (Bkz: Tablo 4).

2016-2017 eğitim öğretim yılı içerisinde İstanbul îli Kadıköy İlçesi'nde fiilen görev yapmakta olan öğretmenler üzerinde yapılan bu araştırmada öğretmenlerin çalışma ortamı ve arkadaşlarına yönelik psikolojik düzeylerini ölçümlemeye çalışılmıştır. Bahsi geçen ölçümleme için belirlenen değişkenler ise ÖPA, ÇADG ve ÖÖ olarak belirlenmiştir. ilgili değişkenlerin yer aldığı bir kavramsal model oluşturularak; alan yazında kabul görmüş olan ölçüm araçlarıyla gerekli ölçümler gerçekleştirilmiştir.

Araştırmaya konu olan değişkenlerden biri olan ÖPA için yapılan değerlendirmelerde öğretmenlerin ortalama sınır değere yakın düzeyde (Ort.=2,60, Std. Sap.= 0,9779) politika algılarının olduğu görülmektedir. Altı ifadeden oluşan Örgütsel Politika Algısı Ölçeği'ne ilişkin ifadelere verilen cevaplara bakıldığında ise en düşük ortalamaya (Ort. $=2,46$, Std. Sap.= 1,125) sahip olan ifadenin ÖPA6 "Bu okulda çalışanlar başkalarından daha iyi görünmek uğruna birbirlerinin açıklarını ortaya çıkarırlar." olduğu tespit edilmiştir. Söz konusu ifadeden araştırmaya katılan öğretmenlerin güvenini zedelemeye yönelik olarak açıkça bir davranış sergilememe gayretinin olduğu söylenebilir. ÖPA2 "Bu okulda çalışanlar, işyeri çıkarlarından daha çok kendi çıkarlarını düşünürler." (Ort.= 2,66 Std. Sap.= 1,151) ve ÖPA3 "Bu okulda çalışanlar, kendilerine yardımı dokunacak kişilere yaranmak için çok fazla zaman harcarlar." (Ort.= 2,67, Std. Sap.= 1,104) ifadelerinde birbirlerine çok yakın ortalama değerlere ulaşımıştır. Anlamlarının, birbirinin oluşumuna zemin hazırladığı düşünülmesi mümkündür. Yakın yapıda olmaları nedeniyle katılımcıların politik davranışın oluşumu için zaman harcayıp; bireysel çıkarlarını maksimize etmeleri açıktır. Ölçek içinde en yüksek ortalamaya (Ort.= 2,68, Std. Sap.= 1,101) sahip olan ifadeye bakıldığında bunun ÖPA5 "Bu okulda çalışanlar, işyerinde var olan gruplara girme yönünde eğilim gösterirler." maddesinde olduğu görülmektedir. Ifade incelendiğinde; tıpkı ÖÖ’de olduğu gibi sosyal kimlik edinimi söz konusudur. Dikkat edilmesi gereken noktaysa; ters yönde bir ediniminin olmasıdır. Yani, politik davranış sergileme intimali yüksek bir yapının varlığını sorgulayan ÖPA'nın bu ifadesinde ÖÖ’ye yönelim düşük seviyededir.

Ölçekte yer alan maddelerin değerlendirilmesinin ardından demografik özelliklerle olan ilişkisine bakıldığında medeni durumun ÖPA oluşmasında anlamlı bir farklılığa yol açmadığı $(p=0,130)$ eşit dağılan varyansların sonucunda $(F=2,024, p=$ $0,156)$ bulgulanmıştır. Bağımsız örneklem t-testine tabi olan bir diğer demografik özellik olan cinsiyetin de varyanslarının eşit dağılım gösterdiği ve aynı zamanda anlamlı bir farklıık oluşturmadığı $(p=0,169)$ görülmektedir. Araştırmamızda elde edilen bulguların birçok çalışmayı (Ferris ve Kacmar, 1992; Ferris vd., 1996; Vigoda ve Cohen, 2002; İşcan, 2005; Mohammed, 2011; Drory ve Beaty, 1991) desteklemezken; Erol'un (2014: 112) ve daha birçok araştırmacının (Kesken, 1999; O'Connor ve Morrison, 2001; Mohan-Bursalı, 2008; Demirel ve Seçkin, 2009; Ayhan, 2013) çalışmasıyla benzer bir sonuç oluşturduğu görülmektedir. Bunu kültürel öğeler ve bunun yansımalarıyla açıklamak uygundur. Toplumumuzda kadınlar örgütsel anlamda politik çaba sergileyememekte ve söz hakkına sahip olamamaktadırlar.

Tek yönlü Anova testi uygulanan demografik değişkenlerden biri olan çalışma yıııın, ÖPA oluşmasında herhangi bir anlamlı farklılığa neden olmadığı $(p=0,503)$ açıktır. ÖPA oluşumunda farklılık yaratmayan ve anlamsız etki oluşturan $(p=0,147)$ bir başka demografik değişkenin birlikte çalışılan öğretmen sayısı olduğu görülmektedir. Elde edilen bu sonucu bireyin geniş bir gruba dâhil olma gereksinimi duymadan özdeşim halinde olduğu daha küçük gruplarla ve hatta yalnızca tek bir bireyle de bireysel çıkarlara erişim için davranış sergileyebileceği anlamı çıkarılabilmektedir. Fakat haftalık çalışma saatinin ÖPA'da önemli ölçüde farklılık oluşturduğu $(p=0,000)$ bulgulanmıştır. Bireyin çalışma saati (nispeten daha fazla saat çalışan öğretmen için) kişisel bakış açısıyla daha fazla örgütsel çıkar elde etme arzusu adeta bir hak ediş gibi sonuç doğurabilmektedir. Eğitim seviyesi $(p=0,036)$ ve yaşa bağlı olarak da $(p=0,019)$ ÖPA oluşumunda anlamlı farklılıklar söz konusudur. Yaşı 18-29 arasında olan öğretmenlerde daha fazla çıkar gözetiminin öne çıktığı bulgulanan araştırmamızda; bu sonucu meslekteki çalışma süresinin aksine bağlı olarak yorumlamak mümkündür. 
Araştırmanın bir başka değişkeni olan ve aynı zamanda bağımlı değişken konumundaki değişkeni ÖÖ kavramı incelendiğinde araştırmaya katılan öğretmenlerin özdeşleşme düzeylerinin (Bkz. Tablo-3) ortalama değerinin sınır değerin üstünde (Ort.: 3,4470 ve Std. Sap.: 0,9522) olduğu görülmektedir. Yapılan bu araştırma sonuçlarına göre öğretmenlerin oldukça iyi olarak ifade edilebilecek düzeyde kurumlarıyla özdeşleştikleri söylenebilir. Bunun yanı sıra, altı ifadeden oluşan Örgütsel Özdeşleşme Ölçeği'nde öğretmenlerin en yüksek ortalamayla (Ort.: 3,72, Std. Sap.: 1,076) temsil ettikleri özdeşleşme ifadesinin de ÖÖ3 kod numaralı "Çalıştığım okuldan bahsederken; "onlar" yerine "biz" ifadesini kullanırım." ifadede olduğu görülmektedir. Verilen cevaplardan elde edilen ortalama değere bakıldığında öğretmenlerin çalışmakta oldukları okullarını fazlasıyla içselleştirip; kendileriyle bir bütün olarak kabul ettikleri anlaşılabilmektedir. Biz olarak ortaya koydukları, insan ilişkilerini kabul ettiklerini destekleyen bir başka verilen cevap da öÖ6 kod numaralı ifadenin karşılığında elde edilen cevapların ortalama değeri olan 3,60'dır (Std. Sap.: 1,070). ilgili maddenin "Eğer, medyada çalıştığım okul hakkında olumsuz yönde eleştirel bir haber çıkmışsa (çıkarsa) bundan rahatsızlık hisseder; utanç duyarım." olduğu bilindiği üzere; öğretmenlerin kurumlarıyla alakalı olarak gerçekleşen iyi veya kötü bir durumun sonucunda çevre ve toplumdan alınacak tepki ve değerlendirmeleri fazlasıyla dikkate aldıkları görülmektedir. Kurumuyla yüksek düzeyde özdeşleşme sergileyen iş görenin kurum dışından gelecek değerlendirmelerin olumlu nitelikte olması için davranışlarını buna göre şekillendirme çabasında olacağı da beklenilmektedir. Örgütle olan özdeşleşmenin iş görenin aynası olacağı unutulmamaktadır. İ̧̧ görenin kendini, kurumunun ayrılmaz bir parçası olarak görmesi ve bunun sonucunda da bir olma duygusu taşıması olan ÖÖ, araştırma sonucunda öğretmenlerin verdiği cevaplardan elde edilen en düşük ortalamaya sahip olan ÖÖ1 kod numaralı ifade de kendini göstererek Reade'nin (2001: 1270) açıklamasını desteklemektedir. İlgili ifadenin "Başka biri çalıştığım okulu eleştirdiğinde, bunu şahsıma yönelik yapılmış olumsuz bir eleştiri, hakaret olarak algılarım." olduğu bilindiği üzere elde edilen ortalama değerin 3,13 (Std. Sap.: 1,205) olarak bulgulandığı görülmektedir. ÖÖ, doğası gereği iş görenle örgüt arasında psikolojik bir bağ kurulması esasına dayanmaktadır (Reade, 2001: 1269), elde edilen ölçek ortalamasına bağlı ortalamalardan hareketle bu bağın kurulduğu açıktır. Elde edilen bulgular sonucunda araştırmaya katılan öğretmenlerin birer üyesi oldukları kurumlarının sahip olduğu özellikleri tıpkı kendilerinin tanımlayıcı birer özelliği olarak benimseme davranışı sergilediği açıktır ve bu da alan yazını (Dutton vd., 1994: 239) destekler durumdadır.

Demografik özelliklere bağlı olarak araştırma değişkenleriyle nasıl farklılaştığına bakabilmek için medeni durum ve cinsiyet için iki bağımsız örneklem t-testi uygulanırken; eğitim düzeyi, yaş, haftalık ders yükü ve mevcut okuldaki çalışma süresi değişkenleri için ise tek yönlü Anova testi gerçekleştirilmiştir. Ölçeğe ilişkin ifadelere bağlı ortalama değerlerin dışında ÖÖ ile demografik özellikler arasındaki ilişkiye bakıldığında bazı anlamlı ve anlamsız farklıık sonuçları ede edilmiştir. Yapılan analizler sonucu elde edilen bulgular ise şöyledir; ÖÖ ile cinsiyet arasındaki ilişkiye bakıldığında, $\mathrm{F}$ test sonucunun anlamlı olmadığı $(F=0,011, p=0,916)$ tespit edilmiştir. Böylece; cinsiyete göre varyansların eşit olduğu kabul edilmektedir. Ayrıca, yapılan t-testine bağlı olarak bulgulara bakıldığında kadın ve erkek öğretmenler arasında ÖÖ’leri bakımından alan yazında derlenen (Özgür, 2015: 48; Özdemir, 2010) çalışmalarda olduğu gibi herhangi anlamlı bir farklılığın olmadığı $(p=0,062)$ görülmektedir. Ancak bunun aksini de bulgulayan çalışmalar da mevcuttur (Nartgün ve Kalay, 2014; Akpınar, 2014: 101). Bir başka demografik özellik olan medeni durumun ÖÖ ile olan ilişkisine bakıldığında tıpkı cinsiyet değişkeninde olduğu gibi varyansların eşit dağılım gösterdiği bulgulanmıştır $(p=0,634)$. Aynı şekilde; evli veya bekâr olan öğretmenlerin ÖÖ bakımından anlamlı bir farklııı̆a yol açmadığı da $\left(t_{(405)}=1,613, p=0,108\right)$ görülmektedir. Yaş değişkeni ele alındığında, yapılan tek yönlü Anova test sonucuna göre ÖÖ üzerinde hiçbir yaş aralığının anlamlı farklılığının olmadığını söylemek mümkündür. Elde edilen bulgular ( $F=1,695, p=0,150)$ öğretmenler üzerinde yapılmış olan bir başka çalışmayla da (Başar, 2011: 121) paralellik göstermektedir. Kurulan ilişkilerin ve çalışma ortamında sosyal kimlik edinimi yaşa bağlı olarak değişmediği açıktır. Öğretmenlerin eğitim durumuna göre ÖÖ üzerinde oluşabilecek anlamlı bir farkın varlığının sorgulanması üzerine elde edilen sonuçlara göre, yaş değişkeninde olduğu gibi benzer şekilde hiçbir anlamlı farklılığa rastlanmamıştır $(F=0,440, p=0,780)$. Söz konusu bulguya benzer bir sonuç öğretmenler üzerinde yapılan daha birçok araştırmayla benzerlik taşımaktadır (Başar, 2011: 122; Demirer, 2014: 200). Haftalık ders yükü saatinin de benzer şekilde ÖÖ düzeyinde anlamlı bir farklılık oluşturmadığı açıktır $(F=0,484, p=0,694)$. Öğretmenlerin görev tanımlarına bağlı olarak değişen çalışma saatleri daha çok bireysel bir öncül niteliğinde olduğu için özdeşleşme düzeyinde anlamlı farklılık oluşturmayışı Bilgiç'in (2011: 74) çalışmasındaki sonuçlarla benzerlik göstererek şaşırtıcı bir sonuç olmadığını ifade etmek mümkündür. Ancak, okuldaki öğretmen sayısı $(F=3,653, p=0,013)$ ve kurumdaki çalışma süreleri $(F=3,661, p=0,001)$ bakımından ÖÖ üzerinde anlamlı farklııklar oluştuğu tespit edilmiştir. Bu durumu, insanların yaradılışı gereği sosyal ve psikolojik birer varlık olmasıyla bağdaştırmak mümkündür. Bir iş gören kendini iyi hissedebileceği bir gruba üye olma eğilimi sergileyeceğinden dolayı ya mevcut bir gruba dâhil olacaktır ya da kendisi yeni bir grup oluşturacaktır. 11-25 öğretmenin birlikte çalıştığı okullardaki öğretmenlerin diğerlerine göre daha yüksek düzeyde (Ort.= 3,60) ÖÖ gösterdiği bulunmuştur. Nispeten daha küçük sayılabilecek bu gibi topluluklarda paylaşımlar daha etkin ve samimi olabileceği için; kurumla olan yakınlaşma da buna bağlı olarak artış gösterecektir. Araştırma sonuçlarına bakıldığında öğretmen sayısındaki artış ÖÖ düzeyinde tam tersi etki yapmaktadır. Kurulan ilişkiler ve düzenlenen etkinliklerdeki yakınlık seviyesi paylaşımın niteliğine göre değişeceği Özgür'ün (2015: 52) öğretmenler üzerinde yaptığı bir başka çalışmayla da desteklenmektedir. Ayrıca, elde edilen bu sonuç Ellemers ve meslektaşlarının (1999), küçük gruplarda yüksek düzeyde özdeşleşme oluşacağı görüşünü desteklemektedir. Biçimsel olarak yapısı belli olan bir sınav sistemi ile meslek edinimi söz konusu olan kamu kuruluşlarında çalışma yılına bağlı olarak araştırmamızda 6-10 yıldır çalışan öğretmenlerin kurumlarıyla daha yüksek düzeyde özdeşleşme 
gösterdiği saptanmıştır. Elde edilen bu bulgu Akpınar'ın (2014: 101) çalışmasıyla tersi yöndedir. Tespit edilen bu farklılığı araştırmanın uygulandığı bölge ve şehirle ilişkilendirebilmek mümkündür. Ancak, Şahin'in (2014: 128) ve Hogde ve Ozag (2007: 136) çalışmasında olduğu gibi öğretmenlerin kurumlarılya özdeşleşme durumları mevcut okuldaki çalışma süresi ile doğru orantılı olarak artış göstermektedir. Bu durum da zamanla biriken dostluklar ve kuruma olan duygusal ve bilişsel bağ|ııkla ilişkilendirebilmeye elverişlidir.

Araştırmanın temel amacı niteliğinde olan ve ÖPA ile ÖÖ ilişkisinde aracılık etkisi oluşturması öngörülen değişken olan ÇADG değişkeni için de tıpkı diğer iki değişken için olduğu gibi maddelere dayalı olarak ortalama hesaplamaları yapılmıştır. Ölçeğin genel ortalaması 3,84 olarak hesaplanmıştır. Elde edilen bu değerin öğretmenlerin çalışma ortamında birbirleriyle yakın, samimi ve güven temelli ilişki içerisinde olduğunun bir temsili niteliğindedir. Sekiz ifadeli "Çalışma Arkadaşlarına Duyulan Güven Ö/çeği"'ne ilişkin en yüksek ortalama değere (Ort.= 3,95, Std. Sap.= 0,915) sahip olan ifadesi ÇAG1 "Çalışma arkadaşlarım her türlü zorlukta bana yardım ederler." olarak bulgulanmıştır. Politik bir tutumdan uzak olunduğunu ortaya koyan bu ifade bireylerin çalışma ortamında birbirlerine yardım etmeye çalışarak destek olma gayretini ifade etmektedir. En düşük ortalamaya sahip olan iki ifadenin ilki ise 3,70 ortalama değerle ÇAG7 "Çalışma arkadaşlarımın arasındaki güven düzeyi çok yüksektir." ifadesinde yer aldığı tespit edilmiştir. Oldukça yüksek bir ortalama değere sahip olan ifadeden, öğretmenlerin aralarında güven problemi yaşamadığı kolaylıkla anlaşımaktadır. Kamuda çalışan öğretmenlerin zaten aynı seçme ve yerleştirme sistemi sonucunda göreve yerleştirildikleri de düşünülürse; eşit koşullarda işe girme ve mümkün oldukça devlet eliyle düzenlenen çalışma yapısı nedeniyle güveni zedeleyecek bir durumla karşılaşma yaşanmamaktadır.

İkinci en düşük ortalama değere (Ort.= 3,74, Std. Sap.= 1,032) sahip olan ifade olarak ÇAG4 "Çalışma arkadaşlarım politik (i̧̧ten pazarlıklı) davranışlar sergilemezler." olduğu tespit edilmiştir. Çalışma arkadaşlarının yine dürüst birer iş gören ve birey olduğu vurgusu yapılan ifadede oldukça yüksek bir ortalama elde edilmiştir. Ayrıca, araştırmanın bağımsız değişkeni konumundaki ÖPA sonuçlarını da doğrular niteliktedir bu sonuç.

Demografik özelliklerle olan ilişkisine bakıldığında; öncelikle araştırmanın bağımsız değişkeni konumundaki ÇADG'nin demografik özelliklerine göre farklılaşma durumuna bakıldığında öğretmenlerin cinsiyetlerine göre ÇADG üzerinde herhangi bir farklılaşmaya yol açmadığı $(p=0,059)$ tespit edilmiştir. Medeni durum için yapılan t-testi sonucunda varyansların homojen dağıım gösterdiği bulgulanmıştır $(F=0,074, p=0,786)$. Fakat tıpkı cinsiyet değişkeninde olduğu gibi ÇADG üzerinde medeni durumun da herhangi bir farklılaşma oluşturmadığı $(p=0,758)$ tespit edilmiştir. Benzer sonuç öğretmenler üzerinde yapılan bir başka çalışma olan Altunel (2015) çalışmasında da bulgulanmıştır. Bir başka demografik değişken olan yaş değişkeninin oluşturduğu grupların varyanslarının eşit dağıldığı tespit edilmiştir $(F=3,069, p=0,863)$. Öğretmenlerin yaşlarına göre bir farklılaşmanın 30-39 yaş arası öğretmenlerle 60 ve üzeri yaşlardaki öğretmenler arasında $(p=0,030)$ olduğu görülmektedir. Benzer bulgulara ulaşan Horuz'un (2014) çalışmasında da tıpkı çalışmamızda olduğu gibi daha yaşlı kabul edilebilecek düzeydeki 60 yaş ve üzeri öğretmenlerin aynı ortamı paylaştığı iş arkadaşlarına daha fazla güvendikleri görülmektedir bulgulara göre. Birlikte geçirilen yıllar ve yaşanan paylaşımlara bağlı olarak bu farklılaşmanın oluşması mümkündür. Aksini bulgulayan çalışma olan yine Altunel (2015) tarafından yapılmıştır. Öğretmenlerin eğitim seviyelerinin ÇADG üzerinde farklılık oluşturduğu rahatlıkla görülmektedir $(p=0,002)$. Horuz'un (2014) öğretmenler üzerinde yaptığı çalışmanın sonuçlarının aksini gösteren bu bulgudan hareketle oluşan farklılığın lise mezunu veya lisansüstü mezunu öğretmenlere kıyasla üniversite mezuniyetine sahip öğretmenlerden kaynaklandığı açıktır $(p=0,040$, Ort. $=3,92)$. Nispeten daha uzun dönemli bir eğitim olan lisans eğitiminde çalışma ortamını deneyimlemek ve çalışma arkadaşlıkları kurabilmek için yeterli sayıda staj yer almaktadır. Buna bağlı olarak henüz öğretmen adayı iken yapılan stajlar ve bu stajlardaki paylaşımlara dayalı kurulan ilişkilerin iş arkadaşıklarında güvenin yerini belirlemeye zemin hazırladığı şeklinde yorumlamak olasıdır. Haftalık çalışma süresinin ÇADG'de anlamlı bir farklılığa yol açmadığı görülürken $(p=0,446)$; daha çok müfredat ve yönetim kaynaklı belirlenen çalışma saatleri bireyler arsında iş yükünü bireysel olarak paylaştırmaktan uzaktır. Yönetim tarafından belirtilen çalışma saatleri güveni etkiler nitelikte değildir. Birlikte çalışılan öğretmen sayısının farklılık oluşturduğu görülmektedir ( $p=0,024)$. 11-25 öğretmenle birlikte çalışan bir öğretmenin 26 ve daha fazla öğretmenle birlikte çalışan bir öğretmene kıyasla daha fazla güven duygusu içinde olduğu bulgulanmıştır (Ort. $=3,99)$. Daha az sayıda bireyle daha etkin ve net iletişim kurabilmenin sağladığı bir avantaj olan yakın ilişki kurabilme karşılıklı güvenin sağlamlığı için oldukça önemli bir alt yapıyı temsil etmektedir denebilir. Öte yandan kurumda çalışma süresine bakıldığında ÇADG için yeterli bir farklılık oluşturmadığı tespit edilmiştir $(p=0,59)$. Bu durumu bir öğretmenin kendini ait veya bir şeyler paylaşmak için yeterli duyusal veya bilişsel bir ortama sahip olmamasına bağlamak olasıdır. Geçen süre değil bu zaman zarfında kurulan ilişkiler veya ait hissedilebilinecek bir grubun mevcut olmadığıyla da açıklamak mümkündür.

Kurulan kavramsal model dâhilinde yapılan analizlere bakıldığında elde edilen sonuçların anlamlılık düzeyleri açıktır (Bkz: Şekil2). Öğretmenlerin ÖPA'larının ÇADG üzerindeki etkisine bakıldığında; negatif yönde bir etkinin varlığı rahatlıkla görülmektedir. Elde edilen bulgulardan hareketle; bireylerin rasyonel karar verirken ikili ilişkilerini göz önüne alarak fayda temelli yönelimlerde bulunduklarını söylemek uygundur. Yani; öğretmenler, kaynak kullanımı, iş yerindeki mevcut gruplarda yer alma çabası, bireysel çıkar gözetimi ve bireyler arası kabul görmede bir başkasının açığını ortaya koyma gibi daha birçok politik davranışı sergilerken ÇADG'yi mutlaka hesaba katarak hareket etmektedirler. Polat'ın (2009: 13) ifadesindeki gibi karşııklı çıkarlarla ilgili olup gereken durumlarda yardımlaşarak birbirlerine açık ve dürüst olunmasıyla ÇADG inşa 
edilmektedir. Bu nedenle bir örgütte ÖPA düzeyi ne kadar azsa tersi oranda da ÇADG oluşacak ve devamlılığı gerçekleşecektir. Hochwarter (2003) ise araştırmasında, çalışanların politik algılarının yüksek olduğu durumlarda, politik faaliyetlerle uğraşmalarının iş doyumları ile örgüte olan bağıııklarını artırdığını; buna karşılık politikanın düşük olarak algılandığı durumlarda, politik davranışlarda bulunan bireylerin iş tatmini ile örgüte olan bağlılıklarının düştüğünü tespit etmiştir. Araştırmanın bir diğer hipotez olan " $H_{1}$ : Öğretmenlerin ÖPA'ları, ÖÖ'leri üzerinde negatif yönde anlamlı etki oluşturur." için yapılan yol analizleri ve korelasyon analizleri bulgularından hareketle hipotezin kabulü söz konusudur.

Araştırmanın sonuçlarına bakıldığında ölçek ortalamaları da bunu ortaya koymaktadır (Bkz: Tablo-6). Güven barındırmayan çalışma ortamlarında buna neden olan bireyler gruptan uzaklaştırılarak bir soyutlanmaya maruz kalır. Örgütsel anlamda ÇADG'yi artırmaya yönelik her bir davranış iş görenleri bütünleştirici etki oluşturmaktadır. Bunu ortaya koyabilen bir iş gören kendini örgütün ayrılmaz bir parçası gibi görerek örgütleriyle özdeşleşmiş olmayı paylaşılan değer ve özellikleri içererek ortaya koymaktadır (Ge ve arkadaşları, 2010). Ayrıca bilinmelidir ki yalnızca güven barındıran ortamlar değil politik davranışı olabildiğince az içeren çalışma ortamlarının da varlığı önem taşımaktadır. Bir zincirin halkaları gibi düşünülebilecek olan bu kavramlar birbirine öncülük etmektedirler. Varlıkları halinde yapıcı veya yıkıcı sonuçları doğurmaktadırlar. Araştırma sonuçlarına bakıldığında da ÇADG 'nin ÖÖ üzerindeki anlamlı etkisinin (Standardize $\beta: 0,275$, Standart hata: 0,066, p: 0,000) bağımsız değişken olan ÖPA değişkeniyle birlikte modele dâhil edilmesinden sonra da (Standardize $\beta: 0,242$, Standart hata: 0,079, p: 0,002) devam ettiği tespit edilmiştir. Bu durumda “ $\boldsymbol{H}_{3}$ : Öğretmenlerin ÇADG düzeyleri, ÖÖ'leri üzerinde pozitif yönde anlamlı etki oluşturur" ile " $\mathrm{H}_{4}$ : Öğretmenlerin ÇADG, ÖPA'nın ÖÖ'ye etkisinde aracılık etkisi oluşturur" hipotezi elde edilen analiz bulguları ve yapılan kısa açıklama dahilinde doğrulanmaktadır.

Öğretmenlerin verdikleri cevaplardan da anlaşılacağı üzere birlikte çalıştıkları bireylerin mevcut kuralları istismar etmek yerine daha yapıcı oldukları ve aralarındaki güven düzeyinin yüksek olduğu yönünde vurgu vardır (Bkz.: Tablo 2). Aydoğan ve Deniz'in (2014) ifadelerini destekleyen bu sonuç ÖPA'nın ÇADG için ciddi manada zemin oluşturduğunun bir ispatıdır. Böylece öğretmenler birbirlerine güven duygusu hissedecektir. ÖPA'nın düşük olduğu örgütlerde güven mekanizması kendiliğinden oluşacağından dolayı daha işbirlikçi ve sakin bir çalışma ortamı olacaktır. Böylelikle, bilgi paylaşımında istekli olma, karşıııklı yardımseverlik ve birbirlerinin sorunları için çözüm odakları olacağı ve kuruma olan bağlılı̆ın ikili ilişkilerle oluşacağı açıktır. Birçok çalışmayla (Büyükdere ve Solmuş, 2006; Yılmaz, 2009; Yılmaz, 2006: 65; i̇slamoğlu, Birsel ve Börü, 2007: 38) ortaya konulan bu sonuç sayesinde araştırmamızın hipotezlerinden " $\boldsymbol{H}_{2:}$ Öğretmenlerin ÖPA'ları, ÇADG üzerinde negatif yönde anlamlı etki oluşturur." alan yazındaki bulgularla örtüşerek kabul edilmektedir.

\section{SINIRLILIKLAR VE ÖNERILER}

Her ne kadar kurumsal amaçlar rasyonellik bakışıyla karlılık elde etmeye odaklı gibi görünse de temelde insan unsuruna devamlıı̆̆ olan bir yatırım mevcuttur. Yapılan bu araştırmanında da temel motivasyonunu insan faktörüyle onun algı ve davranışları oluşturmuştur. Bilişsel, psikolojik ve sosyolojik bir bütünlüğü barındıran insan aynı anda birçok etmene maruz kalarak bazı yönelimlerde bulunmaktadır. Etkileşim ve iletişimin hayati öneminin olduğu çalışma yaşamında bunların da öncülü olan güven ve yapıcı-yıkıcı algılamalar rol oynamaktadır. Politik yaklaşım ve davranışların vücut bulduğu bir çalışma ortamı gerek bireyler arası güveni gerekse bireyin örgütüyle olan özdeşleşmesini olumsuz etkilemektedir. Bu nedenle politik bir davranışın vücut bulduğu ilk anda müdahale yönetim tarafından kaçınılmaz olmalıdır. Bu durumda örgüt içi politika algılamaları mümkün olduğunca giderilmelidir. Çalışanlar arası güvene dayalı ilişkiler inşa edilmesine yönelik girişimler yapılmalıdır. Adil yönetim anlayışı benimsetilerek iş görenlerin kurumla özdeşleşmeleri artırılmalıdır. Dikey yönetim ve iletişim yerine çok yönlü kanallar kullanılarak bireylerin fikirleri ve varsa öneri ve şikayetleri değerlendirilmelidir.

Araştırmacılar için yapılan önerilerse; mevcut bu çalışmayı daha da ileriye götürmeye yöneliktir. Bazı kısıtlar nedeniyle (zaman, enerji ve parasal maliyet) yalnızca Kadıköy'deki devlet okullarında yürütülen çalışma imkânlar ölçüsünde çok daha geniş bir alana ve özel-devlet kıyaslamasına imkân verebilecek şekilde yürütülebilir. Yalnızca nicel değil de nitel araştırma desenleriyle de çok yönlü yorumlanacak şekilde tasarlanabilir yönündedir.

\section{KAYNAKÇA}

Akdoğan, A. ve Demirtaş, Ö. (2014), Etik Liderlik Davranışlarının Etik İklim Üzerindeki Etkisi: Örgütsel Politik Algılamaların Aracılık Rolü, Journal of Economics and Administrative Sciences, 16(1), pp. 103-120.

Akpınar, A. (2014), Okullardaki İnsan İlişkileri Düzeyi İle Öğretmenlerin Örgütsel Özdeşleşme Düzeyleri Arasındaki iliş̧ki, Yayınlanmış Yüksek Lisans Tezi, Uşak Üniversitesi Sosyal Bilimler Enstitüsü, Uşak, 101.

Altunel, A. T. (2015). Örgütsel Güven Düzeyi İle Örgütsel Adanmışlık Düzeyi Arasındaki illişki: Bir Araştırma. Yüksek Lisans Tezi. İnönü Üniversitesi Sosyal Bilimler Enstitüsü İşletme Anabilim Dalı Yönetim Ve Organizasyon Bilim Dalı, Malatya.

Andrews, M. C., Witt, L. A., and Kacmar, K. M. (2003), The interactive effects of organizational politics and exchange ideology on manager ratings of retention. Journal of Vocational Behavior, 62, 357-369. 
Ashforth, B.E. ve Mael, F. (1989). Social Identity Theory and the Organization. Academy of Management Review, 14 (1), $20-39$.

Aydoğan, E. ve G. Deniz (2014). Sosyo-Teknik Kolaylaştırıcıların Bilgi Paylaşımı ve Algılanan Örgütsel Performans Üzerindeki Etkileri: Konaklama İşletmelerinde Bir Araştırma. Erciyes Üniversitesi Sosyal Bilimler Enstitüsü, 1(34-59).

Ayhan, Ö. (2013). Algılanan örgütsel politikanın örgütsel adalet ve işten ayrılma niyetine etkisi. Yayınlanmamış yüksek lisans tezi, Gebze Yüksek Teknoloji Enstitüsü, Kocaeli.

Balay, R. (1999)., İşgörenlerin Örgütsel Bağlılık Etkenleri Ve Sonuçları, Ankara Üniversitesi Eğitim Bilimleri Fakültesi Dergisi, Cilt:32, Sayı:1, S.237-246.

Baron, M. ve Kenny, D. A. (1986). Themoderator-mediator variable disrinction in social psychological research: Conceptual, strategical dstatistical conderations. Journal of personalityand social psychology, 51(6), 1173-1182.

Bartlett, J. E., Körtlik, J. W. ve Higgins, C. C. (2001). Organizational research: Determining appropriate sample size in survey research. Information Technology, Learning and Performance Journal, 19(1), 43-50.

Bartel, C. A. (2001). "Social Comparisons in Boundary-Spanning Work: Effects of Community Outreach on Members' Organizational Identity and Identification", Administrative Science Quarterly, Vol. 46, No. 3 (Sep., 2001), pp. 379-413.

Başar, U., (2011), Örgütsel Adalet Algısı, Örgütsel Özdeşleşme Ve İş Tatmini Arasındaki İlişkilere Yönelik Görgül Bir Araştırma, Yayınlanmış Yüksek Lisans Tezi, Kara Harp Okulu Savunma Bilimleri Enstitüsü Savunma Yönetimi Ana Bilim Dalı, Ankara, 121.

Başar, U., Alan, H., Topçu, M.K. ve Aksoy, S. (2015). "Örgütsel Politika Algısının Ardılları Üzerine Görgül Bir Araştırma". 3. Örgütsel Davranış Kongresi, Tokat.

Bergami, M. ve Bagozzi, R.P. (2000). Self Categorization, Affective Commitment and Group Self Esteem As Distinct Aspects of Social Service Quality, British Journal of Social Psyschology, 39, 555-557.

Bilgiç, Ö. (2011). Illköğretim okulu öğretmenlerinin örgütsel güven düzeyine ilişkin algıları. Yıldız Teknik Üniversitesi, Sosyal Bilimler Enstitüsü, Eğitim Bilimleri Anabilim Dalı, Eğitim Yönetimi ve Denetimi Bilim Dalı, İstanbul, Türkiye.

Büyükdere, B. ve Solmuş, T. (2006). İş ve özel yaşamda kişilerarası güven. http://www.isguc.org/?avc=arc_view. php\&ex=271\&pg=m. adresinden 10 Mart 2007 tarihinde edinilmiştir.

Cheney, G. (1983). On the various and changing meaning of organizational membership: A fi eld study of organizational identifi cation. Communication Monographs, 50, 342-362.

Cheung, M. F. Y. ve Law M. C. C. (2008). “Relationships of Organizational Justice and Organizational Identification:The Mediating Effects of Perceived Organizational Support in Hong Kong", Asia Pacific Business Revie, 14 (2): 213-231.

Creswell, J. W. (2014). A concise introduction to mixed methods research. California: SAGE.

Cropanzano R., Howes J.C., Grandey A.A. ve Toth P. (1997), "The relationship of organizational politics and support to work behaviors, attitudes, and stress", Journal of Organizational Behavior, 18, 159-180.

Daboval, J., Comish, R., Swindle, B., \& Gaster, W. (1994). Trust İnventory for Small Businesses, Small Bisinesses Symposium. htp:/wwww.sbaer.uca..edu/docs/proceedings/94sw031.txt

Deluga, R. C. (1994), "Supervisor Trust Building, Leader-Member Exchange And Organizational Citizenship Behavior". Journal of Occupational \& Organizational Psychology, 67(4), 315-326.

Demirel, Y. (2008). “Örgütsel Güvenin Örgütsel Bağlılık Üzerine Etkisi: Tekstil Sektörü Çalışanlarına Yönelik Bir Araştırma”. Yönetim ve Ekonomi, 15(2), 179-194.

Demirel, Y. ve Seçkin, Z. (2009). Örgüt içi politik davranışların tespiti üzerine Kırgızistan'da sağlık sektöründe bir araştırma. Uluslararası Stratejik Araştırmalar Kurumu. OAKA, 4 (7), 143-161.

Demirer, S., (2014), Öğretmenlerin Örgütsel Sosyalleşme ve Özdeşleme Düzeyleri İle Birlikte Çalışma Yeterlikleri Arasındaki illişki, Yayınlanmış Yüksek Lisans Tezi, Abant İzzet Baysal Üniversitesi Eğitim Bilimleri Enstitüsü, Bolu, 200.

Demirtaş, H.A. (2003). Sosyal Kimlik Kuramı, Temel Kavram ve Varsayımları, iletişim: Araştırmaları, Bahar, 1 (1), $123-144$.

Drory, A. ve Beaty, D. (1991). Gender differences in the perception of organizational influence tactics. Journal of Organizational Behaviour, 12, 249- 258.

Durdağ, M. ve A. Naktiyok (2011). "Psikolojik Taciz Algısının Örgütsel Güven Üzerindeki Rolü", Kafkas Üniversitesi iißBF Dergisi, 1-2.

Dutton, J., Dukerich, J. ve Harquail, C.V. (1994). Organizational Images and Membership Commitment, Administrative Science Quarterly, 34, (2), $239-263$.

Ellemers, N. K. P. ve Ouwerkerk, J. W. (1999), "Self-Categorization, Commitment To The Group And Group Self-Esteemas Related But Distinct Aspects Of Social Identity" European Journal Of Social Psychology, 29, 3, 371-389. 
Erol, E., (2014). Eğitim fakültelerinde örgütsel iklim ile örgütsel politika algısı arasındaki ilişki. Pamukkale Üniversitesi Eğitim Bilimleri Enstitüsü Eğitim Bilimleri Ana Bilim Dalı Eğitim Yönetimi, Denetimi, Planlaması Ve Ekonomisi Bilim Dalı, Yayımlanmamış doktora tezi. Denizli.

Ferres, N., Connell, J., ve Travaglione, A. (2004), Coworker Trust As A Social Catalyst For Constructive Employee Attitudes. Journal of Managerial Psychology, 19(6), 608-622.

Ferris, G. R. ve Kacmar, K. M. (1992), Perceptions of Organizational Politics, Journal of Management, 18 (1), 93-116.

Ferris, G. R., Frink, D. D., Galang, M. C., Kacmar, K. M. ve Howard, J. L. (1996). Perceptions of organizational politics prediction: Stressrelated implications and outcomes. Human Relations, 49 (2), 233-266.

Freud, SIgmund (1938). Abriss der psychoanalyse Internat. Zschr. Psychonal. Image,25,pp.7-6

Gautam, T., Van Dick, R. ve Wagner, U. (2004). Organizational Identification and Organizational Commitment: Distinct Aspects of Two Related Concepts, Asian Journal of Social Psychology, Vol: 7, No: 3, pp. 301-315.

Ge, J., Su, X. ve Zhou, Y. (2010). Organizational Socialization, organizational identification and organizational citizenship behaviour an empirical research of Chinese high-tech manufacturing enterprises. Nankai Business Review International, 1, 2, 166-179.

Gilbert, J. A. ve Tang, T. Li-Ping. (1998), An Examination of Organizational Trust Antecedents. Public Personnel Management, 27(3), 321338.

Gioia, D.A., Schultz, M. ve Corley, K.G. (2000). Organizational Identity, Image andAdaptive Instability, Academy of Management Review, 25 (1):63-82.

Hochwarter, W.A. (2003). The Interactive Effects of Pro-Political Behavior and Politics Perceptions on Job Satisfaction and Affective Commitment, Journal of Applied Social Psychology, (33) 7.

Hogde, M., E. ve Ozag, D. (2007), The Relationship Between North Carolina Teachers Trust and Hope and Their Organizational Commitment, The Delta Pi Epsilon Journel, No:2, Spring/Summer, pp. 128-137.

Hogg, M.A. ve Terry, D.J. (2000). Social Identity and Self-Categorization Processes in Organizational Context, The Academy of Management Review, 25 (1), 121-140.

Horuz, F. I. (2014). Mesleki Doyum ve Örgütsel Güven Arasındaki Illişki: Özel Eğitim ve Rehabilitasyon Merkezlerinde Görev Yapan Sınıf Öğretmenleri Üzerinde Bir İnceleme. Yüksek Lisans Tezi. Yeditepe Üniversitesi Eğitim Bilimleri Enstitüsü Eğitim Yönetimi ve Denetimi Anabilim Dalı, i̇stanbul.

İslamoğlu G., Birsel, M. ve Börü, D. (2007), Kurum İçinde Güven: Yöneticiye, İş Arkadaşlarına ve Kuruma Yönelik Güven Ölçümü, İstanbul: Inkılap Kitabevi

İşcan, Ö. F. ve Naktiyok, A. (1990). Çalışanların Örgütsel Bağdaşımlarının Belirleyicileri Olarak Örgütsel Bağılıık ve Örgütsel Adalet Algılan, Ankara Üniversitesi SBF Dergisi, 59.1.

Işcan, Ö. F. (2005). Siyasal arena metaforu olarak örgütler ve örgütsel siyasetin örgütsel adalet algısına etkisi. Ankara Üniversitesi SBF Dergisi, 60 (1), 149-171.

Kacmar, K. M., ve Carlson, D. S. (1997). Further validation of the perceptions of politics scale (POPS): A multiple sample investigation. Journal of Management, 23 (5), 627- 658.

Kamer, M. (2001). Organizational trust, organizational commitment and organizational citizenship behavior. (Unpublished Master Thesis), Marmara University Institute of Social Sciences, Istanbul, Turkey.

Karatepe, O. (2011). Perceptions of Organizational Politics and Hotel Employee Outcomes, International Journal of Contemporary Hospitality Management, Vol. 25 No. 1, s.82-104.

Kesken, J. (1999). Örgütsel politika ve yansımaları. Yayımlanmamış doktora tezi, Dokuz Eylül Üniversitesi Sosyal Bilimler Enstitüsü, İzmir.

Kiewitz, C., Hochwarter, W.A., Ferris, G.R. ve Castro, S.L. (2002). The Role of Psychological Climate in Neturalizing the Effects of Organizational Politics on Work Outcomes, Journal of Applied Social Psychology, Vol. 32, No.6.

Kling, A.S., (2004), Commitment to Organizational Change: Assessing The Effects of Identifying Benefits To Change and Its Relationship With Organizational Trust, Doktora Tezi, Alliant International University.

Lapierre, L.M. (2007). Supervisor trustworthiness and subordinates' willingness to provide extra-role efforts. Journal of Applied Social Psychology, 37, 272-297.

Lee, S. M. (1971). An Empirical Analysis of Organizational Identification, The Academy of Management Journal, Vol. 14, (2), 213-226.

Mael, F.A. ve Ashforth, B.E. (1992). Alumni and Their Alma Mater: A Partial Test of the Reformulated Model of Organizational Identification, Journal of Organizational Behavior, 13 (2), 103-123.

Mael, F. ve B. E. Ashforth. (2001). Identification in work, war, sports, and religion: contrasting the benefits and risks. Journal for The Theory of Social Behavior, XXXI, 2, $197-222$. 
Meydan, H.C. ve Şeşen, H. (2011), Yapısal Eşitlik Modellemesi AMOS Uygulamaları, Detay Yayıncılık, Ankara.

Mintzberg, H. (1983). Power in and around organizations. Englewood Cliffs, Prentice-Hall, NJ.

Mintzberg, H. (1985). The organization as political arena. Journal of Management Studies, 22 (2), 133-154.

Mohammed, A. E. (2011). Örgüt kültürü ve psikolojik iklimin politik davranış algılamaları üzerindeki etkileri: Kayseri'de bir araştırma. Yayımlanmamış yüksek lisans tezi, Erciyes Üniversitesi Sosyal Bilimler Enstitüsü, Kayseri.

Mohan-Bursalı, Y. (2008). Örgütsel politikanın işleyişi: Örgütsel politika algısı ve politik davranış arasındaki ilişkiler. Yayımlanmamış doktora tezi, Dokuz Eylül Üniversitesi Sosyal Bilimler Enstitüsü, İzmir.

Mowday, R. T. (1998), Reflections On The Study And Relevance Of Organizational Commitment. Human Resources Management Review, $8(4), 387-401$.

Nartgün, Ş.S. ve Kalay, M. (2014). Öğretmenlerin Örgütsel Destek, Örgütsel Özdeşleşme İle Örgütsel Sinizm Düzeylerine i̇lişkin Görüşleri. Turkish Studies-International Periodical For The Languages, Literature and History of Turkish or Turkic, 9(2), 1361-1376.

O'Connor, W. E., ve Morrison, T. G. (2001). A comparison of situational and dispositional predictors of perceptions of organizational politics. The Journal of Psychology, 135 (3), 301-312.

Oliver, D., ve Roos, J. (2003), Studying organization Identity Empirically: A Review, Working Paper 31, September 2003, Imagination Lab Foundation, Lausanne -Switzerland,

Olkkonen, M. E. ve Lipponen, J. (2005). Relationships between organizational Justice, identifi cation with organization and work unit, and group-related outcomes. Organizational Behavior and Human Decision Process.

Özdemir, A. (2010). Örgütsel Özdeşleşmenin Algılanan Örgütsel Destek, Cinsiyet ve Kıdem Değişkenlerine Göre İncelenmesi. Türkiye Sosyal Araştırmalar Dergisi, 14(1), 237- 250.

Özgür, E. Ö., (2015), Algılanan Örgütsel Prestij, Örgütsel Özdeşleşme Ve Öğrenci Başarısı Arasındaki İlişkilerin İncelenmesi, Yayınlanmış Yüksek Lisans Tezi, Mevlâna Üniversitesi Sosyal Bilimler Enstitüsü Eğitim Yönetimi Teftişi Planlaması Ve Ekonomisi Anabilim Dalı, Konya, 48.

Parker, C. P., Dipboye, R. L., and Jackson, S. L. (1995). Perceptions of organizational politics: An investigation of antecedents and consequences. Journal of Management, 21 (5), 891-912.

Patchen, M. (1970). Participation, achievement, and involvement on the job. Englewood Cliffs, NJ: Prentice Hall.

Pfeffer, J. (1992). Managing with powers: Understanding Power in organizations. Harward Business School Press, Boston.

Polat, S. (2007). Ortaöğretim Öğretmenlerinin Örgütsel Adalet Algıları, Örgütsel Güven Düzeyleri İle Örgütsel Vatandaşlık Davranışları Arasındaki İlişki. Basılmamış Doktora Tezi. Kocaeli Üniversitesi Sosyal Bilimler Enstitüsü.

Polat, S. (2009), Eğitim Örgütleri İçin Sosyal Sermaye Örgütsel Güven. Ankara: Pegem Akademi.

Reade, C. (2001), "Antecedents of Organizational Identification in Multinational Corporations: Fostering psychological Attachment to The Locak Subsidiary and The Global Organization", Journal of Human Resource Management, XII, 8, 1269 - 1291.

Rousseau, D.M. (1998). Why Workers Still Identify with Organizations, Journal of Organizational Behavior, 19, $217-233$.

Shaw, R. B. (1997), Trust In The Balance: Building Successful Organizations On Results, Integrity, And Concern. San Francisco: Jossey-Bass.

Sobel, M.E. (1982). Asymptotic confidence intervals for indirect effects in structural equation models. Sociological Methodology, 13, 290312 .

Şahin, E., (2014), Ortaöğretim Kurumlarında Örgütsel Kimlik, Örgütsel İmaj, Örgütsel Özdeşleşme ve Örgütsel Adalet (Bursa Örneği), Yayınlanmış Yüksek Lisans Tezi, Ege Üniversitesi Sosyal Bilimler Enstitüsü Eğitim Bilimleri Anabilim Dalı Eğitim Yönetimi, Teftişi, Ekonomisi Ve Planlaması Bilim Dalı, İzmir, 128.

Tajfel, H. (1978). Differentiation Between Social Groups: Studies in the Social Psychology of Intergroup Relations, European Monographs in Social Psychology, Academic Press, 14, London.

Tajfel, H., ve Turner, J. C. (1979). An integrative theory of intergroup conflict. In W. G. Austin ve S. Worchel (Eds.), The Social Psychology Of Group Relations: 33-47, Monterey, CA, Brooks-Cole.

Tajfel, H. ve Turner, J. C. (1986). The Social Identity Theory Of Intergroup Behavior in S. Worchel ve W. G. Austin (Eds.). The Psychology Of Intergrou Relations, 2, 7-24, Chicago, Nelson Hall.

Tak, B. ve Çiftçioğlu, A. (2009). Algılanan Örgütsel Prestij Ġle Örgütsel Bağlılık ve Örgütsel ÖzdeG̣leG̣me Arasındaki ilişkilerin İncelenmesine Yönelik Bir Araştırma, Akdeniz Iktisadi ve Idari Bilimler Fakülte Dergisi, 18, 100-116.

Tak, B. ve Aydemir, B.A. (2004). Örgütsel Özdeşleşme Üzerine İki Görgül Çalışma, 12. Ulusal Yönetim ve Organizasyon Kongresi, Uludağ Üniversitesi, Bursa.

Tan, H. H. ve Tan, C. S. (2000), Toward The Differentiation Of Trust İ Supervisor And Trust In Organization. Genetic, Social and General Psychology Monographs, 126(2), 241-260. 
Tüzün, I.K., (2006), Örgütsel Güven, Örgütsel Kimlik ve Örgütsel Özdeşleşme ilişkisi; Uygulamalı Bir Çalışma, Doktora Tezi, Gazi Üniversitesi. Valle, M. ve Witt, L. A. (2001), The Moderating Effect of Teamwork Perceptions on the Organizational Politics-Job Satisfaction Relationship, The Journal of Social Psychology, 141(3), pp. 379-388.

Van Dick R. (2001). Identification in Organizational Context: Linking Theory and Research from Social and Organizational Psychology, International Journal of Management Reviews, 3 (4), 265-283.

Van Knipperberg, D. ve Van Schie, E.C.M. (2000). Foci and Correlates of Organizational Identification, Journal of Occupational and Organizational Psychology, 73-137.

Vigoda, E. (2000). The relationship between organizational politics, job attitudes, and work outcomes: Exploration and implications for the public sector. Journal of Vocational Behavior, 57, 326-347.

Vigoda, E., ve Cohen, A. (2002). Influence tactics and perceptions of organizational politics a longitudinal study. Journal of Business Research, 55 (4), 311-324.

Vigoda-Gadot, E., H. Vinarski-Peretz ve E. Ben-Zion (2003), Politics and Image in the Organizational Landscape: An Empirical Examination among Public Sector Employees, Journal of Managerial Psychology, 18(8), 764-787.

Vigoda-Gadot, E. ve Talmud, I. (2010). Organizational politics and job outcomes: The moderating effects of trust and social support. Journal of Applied Social Psychology, 40 (11), 2829-2861.

Walumbwa, F. O., Avolio, B. J. ve Zhu, W. (2008). How Transformatıonal Leadership Weaves Its Influence on Individual Job Performance: The Role of Identification and Efficacy Beliefs, Personnel Psychology, 61: 793-825.

YıImaz, E. (2005). Validity and reliability study of organizational trust scale at schools. Selcuk University- Institute of Social Science Journal, $14,739-756$.

Yılmaz, E. (2006). Okullardaki örgütsel güven düzeyinin okul yöneticilerinin etik liderlik özellikleri ve bazı değişkenler açısından incelenmesi (Yayımlanmamış doktora tezi). Selçuk Üniversitesi, Konya.

Yılmaz, K. (2009). Özel dershane öğretmenlerinin örgütsel güven düzeyleri ile örgütsel vatandaşlık davranışları arasındaki ilişki. Kuram ve Uygulamada Eğitim Yönetimi, 15 (59), 471-490.

Young, J.T., (2009), The Newcomer's Path To Trust: Trust-Building Strategies, Experienced Trust, And Employee Engagement Among NewlyHired Employees, Doktora Tezi, University of Washington. 